\title{
L'atribució hipotètica de Curial e Güelfa a Enyego d'Àvalos (Consideracions sobre un «informe» de L. Badia i J. Torró)
}

\author{
Curial e Güelfảs hypothetical attribution to Enyego d'Àvalos \\ (Considerations on a «report» by L. Badia and J. Torró)
}

ABEL SOLER

abel_soler@yahoo.com

Universitat de València

\begin{abstract}
Resum: La revista Estudis Romànics 39 (2017) ha publicat el meu article: "Enyego d'Àvalos, autor del Curial e Güeffa?", que resumeix una part de la meua tesi doctoral, La cort napolitana d'Alfons el Magnànim: el context del «Curial e Güelfa» (Universitat de València, 2016). L'article defensa la hipòtesi que Enyego d'Âvalos -natural de Toledo, educat a València, conseller de Felip Maria Visconti i gran camarlenc d'Alfons el Magnànim, al regne de Nàpols- hauria estat l'autor de la novel la cavalleresca anònima Curiale Güelfa. Encara que la tesi és inèdita, Lola Badia i Jaume Torró s'han manifestat en contra de la hipòtesi mitjançant declaracions difamatòries en mitjans de comunicació i un Informe molt tendenciós. El meu propòsit en aquest article és rebatre els arguments suposadament científics de Lola Badia i Jaume Torró, posar en evidència els seus prejudicis $i$ tergiversacions, $i$ reivindicar el meu dret a aportar els resultats de la meua recerca i a expressar liurement les meues interpretacions. La meua tesi, fruit d'anys de treball arxivístic i bibliogràfic, ha estat elaborada d'acord amb una rigorosa metodologia científica. La insòlita reacció de Badia i Torró obeeix al fet que la meua hipòtesi qüestiona una gran part dels plantejaments d'ambdós investigadors, els quals han provocat una gran desorientació, ja que situen el Curial en les corts ibèriques del Trastàmara i no en les corts del duc de Milà i del rei de Nàpols, en contacte amb l'humanisme italià.
\end{abstract}

Paraules clau: Curial e Güelfa, Enyego d'Àvalos, València, Milà, Nàpols, Alfons el Magnànim, Lola Badia, Jaume Torró

\begin{abstract}
The journal Estudis Romànics, 39 (2017) has just published my article "Enyego de Avalos, author of the Curial e Guelfa?", which summarizes a part of my thesis, L a cort napolitana d'Affons el Magnanim: el context del «Curiale Gü̈effar (University of València, 2016). It supports the hypothesis that Enyego d'Àvalos - a native of Toledo, educated in Valencia, Philip Maria Visconti's counselor and great Chamberlain of Alfons the Magnanimous, at the Kingdom of Naples- would have been the author of the chivalric anonymous romance Curiale Gueffa. Although unpublished thesis, Lola Badia and Jaume Torró have spoken out against my hypothesis through defamatory statements to the media and a very biased report. My purpose in this article is to refute the supposedly scientific arguments of Lola Badia and Jaume Torró, highlight their prejudices and misunderstandings and claim my right to make my own research and to freely express my interpretations. My thesis, which is the result of years of work in archives and analysis of a selected bibliography, has been prepared in accordance with rigorous scientific methodology. The unusual reaction of Badia and Torró is due to the fact that my hypothesis invalidates many of their approaches, which have caused great confusion among historins of medieval literature, because they place Curial in the Iberian courts of the Trastamara royal family and not in the courts of the duke of Milan and of the King of Naples, in touch with Italian humanism.
\end{abstract}

Keywords: Curiale Güelfa, Enyego d’Àvalos, Valencia, Milan, Naples, Alfons the Magnanimous, Lola Badia, Jaume Torró 
Abel Soler. L'atribució hipotètica de Curial e Güelfa a Enyego d'Àvalos (Consideracions sobre un «informe» de L. Badia i J. Torró)

\section{La difusió inicial de l'atribució hipotètica}

El 28 de novembre del 2016, vaig defensar al si de la Universitat de València la meua tesi doctoral, $L a$ cort napolitana d'Alfons el Magnànim: el context de «Curial e Güelfa», dirigida per Antoni Ferrando Francés, catedràtic de Filologia Catalana de dita universitat. Per a mi fou una immensa satisfacció que el tribunal que la va jutjar, format per eminents especialistes, em concedira la màxima qualificació acadèmica. La tesi, amb lectura aprovada per l'Escola de Doctorat de la Universitat de València en setembre del 2016, havia sigut exposada a la consulta pública de la comunitat científica durant el mes d'octubre. Entre els molts aspectes abordats en la tesi, destaca, per la novetat, la proposta d'autoria per a la referida novel la anònima a favor d'Enyego d'Àvalos. Un resum de la hipòtesi, «Enyego d'Àvalos, autor de Curial e Güelfa?», es donà a conéixer vers la fi de febrer del 2017 en la prestigiosa revista de l'Institut d'Estudis Catalans (IEC), Estudis Romànics, 39 (2017), pp. 137-165, després d'haver sigut sotmesa a la preceptiva avaluació externa i d'haver incorporat les observacions pertinents dels avaluadors. La notícia de la publicació es va publicitar a través del núm. 217 (febrer del 2017) del Butlletí electrònic de l'IEC:<http://www.iec.cat/Comunicacio_IEC/ER39_Abel_Soler.pdf >

La referida notícia recollia gran part del contingut d'un comunicat de premsa de la Universitat de València, on s'anunciava la conferència «Les claus per al descobriment de l'autor de Curial e Gü̈lfa», que vaig pronunciar a l'Aula Magna de la Universitat de València el 27 de febrer del 2017, a proposta del vicerector de Cultura, el Dr. Antoni Ariño. La nota de l'IEC contenia un enllaç amb l'esmentat article d'Estudis Romànics: $<$ http://www.iec.cat/activitats/noticiasencera.asp?id_noticies=1899>

En atenció a l'interés científic de la proposta sobre l'autoria del Curial plantejada en aquest article d'Estudis Romànics, la presidència de l'IEC va organitzar la conferència «Curial e Güelfa: text català, context italià», que vaig pronunciar a la sala Pi i Sunyer de l'IEC el 6 d'abril del 2017, precedida d'unes paraules de presentació de Joan Veny, director d'Estudis Romànics, i d'Antoni Ferrando, director de la meua tesi de doctorat.

El contingut de la tesi es farà públic a partir del dia 28 de novembre del 2017. El meu article d'Estudis Romànics es limita a oferir un primer avançament, forçosament simplificat, de la hipòtesi d'autoria del Curial a favor d'Enyego d'Àvalos. La tesi pretén aportar respostes concretes als molts interrogants que planteja la novel la anònima, no documentada més enllà del manuscrit de la BNE de Madrid (Ms. 9750), una còpia molt pròxima a l'original, probablement perdut per sempre. L'article i l'orientació acadèmica de la tesi se situen en la mateixa línea traçada per Maria Teresa Ferrer i Mallol (2011) en un article on localitzava el Curial a Itàlia i en l'entorn de Lluís Sescases. Com a historiador i medievalista de formació prèvia, he seguit molt de prop el seu sistema de treball, amb una diferència, si de cas: abans d'aplicar el mètode prosopogràfic, em vaig documentar, tan exhaustivament com vaig poder, sobre els més diversos aspectes literaris, lingüístics i historicoculturals de la novel la. El meu objectiu era explicar-la globalment. M'han servit de molt les notes sobre les fonts del Curial que recull l'edició de l'obra realitzada per Lola Badia i Jaume Torró (2011) i les aportacions dels Estudis lingüístics i culturals sobre «Curiale Güelfa» (2012a [2007-2010]), coordinats per Antoni Ferrando. 
Abel Soler. L'atribució hipotètica de Curial e Güelfa a Enyego d'Àvalos (Consideracions sobre un «informe» de L. Badia i J. Torró)

Badia i Torró, historiadors de la literatura catalana, s’interessen pel Curialbàsicament com un producte literari. Parteixen de l'afirmació que la novel la «fue escrita en un ambiente ibérico relacionado con las cortes de los Trastámaras»; no se'n coneix «ni autor, ni fecha, ni dedicatoria, ni rúbricas», raó per la qual consideren que aquestes són «pérdidas irreparables sobre las que es mejor no insistir» (Badia / Torró 2010: 43). En la Introducción a l'edició de Quaderns Crema (2011: 9), expliquen que amb aquesta es «vol ajudar a fixar la idea que el Curial es un producte literari d'una qualitat excepcional» $\mathrm{i}$ «aclarir tot el que han pogut esbrinar a propòsit de la cultura de l'Anònim i de la seva manera d'entendre el guiatge de Boccaccio, Dante i Petrarca».

A diferència dels objectius estrictament literaris de Badia i Torró, les meues orientacions, com a medievalista i historiador de la cultura que sóc, responen a criteris assentats des de fa dècades per l'escola francesa dels Annales, segons els quals tota obra literària és també un document interrogable històricament. ¡I molt més encara una novel la cavalleresca, farcida d'al lusions a personatges i de situacions del segle XV! També el segle passat va conéixer moviments com el New Historicism, tendents a superar improductives maneres d'aproximar-se a un text literari com si aquest fóra un objecte solament interrogable en close reading, és a dir, interpretable prescindint de l'autoria, el context social i històric, etc.

En conseqüència, l'orientació acadèmica del meu treball ha sigut i és pluridisciplinària, atés que integra les dades literàries amb les dades històriques i lingüístiques, i d'altres derivades de diferents disciplines auxiliars. Segons el meu criteri, és una orientació imprescindible per a una interpretació adequada de l'obra i per a la comprensió congruent de la intenció literària de l'autor. El ric rerefons històric i cultural del Curial talment ho reclama. Seguisc, per tant, les pautes de Jordi Rubió en la seua Historia de la literatura catalana (1953) i de tots els historiadors de la cultura i la literatura catalanes que s'inspiren en el seu magisteri. Aprofundisc, a més, en les orientacions de Júlia Butinyà, autora des del 1987 de més de trenta contribucions sobre el Curial, poc tingudes en compte o directament ignorades per Badia i Torró, pel fet d'haver negat aquests durant anys les connexions del Curial amb l'humanisme i la contextualització de l'obra en la Itàlia d'Alfons el Magnànim. També aprofite les observacions de caràcter històric de diversos treballs d'Anton M. Espadaler, críticament analitzats. Aprofundisc, en fi, en l'estudi dels personatges històrics del Curial, en la línia de Maria-Teresa Ferrer i Mallol (2011) i, concretament, en la possible identificació de l'autor del Curial, que la recercadora catalana va concretar hipotèticament en Lluís Sescases, bibliotecari del rei Alfons el Magnànim i, durant un temps, secretari d'Enyego d'Àvalos. I, òbviament, m'han servit de molt les orientacions d'Antoni Ferrando, historiador de la llengua i la cultura catalanes, que el 1989 ja va dibuixar un Curial centrat a Itàlia, a partir de la constatació de nombroses referències i fonts històriques i literàries italianes -entre les quals, alguns commenti de Dante-, i que el 2012, en el seu article sobre «Precaucions metodològiques per a l'estudi lingüístic del Curiah», va traçar una ben perfilada caracterització lingüística de la novel la i un retrat quasi exacte del desconegut autor.

Aquesta línia de contextualització italiana i de caracterització lèxica occidental i valenciana del Curial és la que refermen, en conjunt, els trenta-vuit Estudis lingüistics i culturals sobre «Curial e Güelfa» 
Abel Soler. L'atribució hipotètica de Curial e Güelfa a Enyego d'Àvalos (Consideracions sobre un «informe» de L. Badia i J. Torró)

([2007-2010] 2012) editats pel mateix Ferrando, en els quals col laboraren especialistes nacionals i estrangers com Germà Colón, Albert Hauf, Joan Veny, Max Wheeler, Carles Miralles, Isabel de Riquer, Beatrice Schmid, Curt Wittlin, Rafael Beltran, Annamaria Annicchiarico, Anna Maria Compagna, Anna Maria Babbi, Gemma Avenoza, Júlia Butinyà i Anton M. Espadaler, entre d'altres. Una gran part d'aquestes aportacions desenvolupen els continguts de ponències llegides en els Encontres sobre el Curial celebrats a la Universidad Menéndez Pelayo (Santander, 2007) i a la Seu de la Nucia de la Universitat d'Alacant (2008). Entre els participants, també s’hi trobava Jaume Torró (Badia / Torró 2011: 726), l'aportació del qual, per urgències d'acreditació acadèmica, va decidir traslladar a la Revista de Literatura Medieval (2012). Alguns dels resultats d'aquestes aportacions van ser aprofitats per a l'edició «crítica i comentada» de Badia i Torró del 2011. Per exemple, dades referides a la trajectòria de famosos cavallers europeus de l'època (aspecte analitzat per Rafael Beltran), al lèxic (aspecte estudiat per Colón) o a la influència que van exercir en el Curial diversos commenti de Dante (aspecte àmpliament il lustrat per Juan Francisco Mesa). Les intervencions de Colón i Veny es van publicar ja el mateix anys 2011.

Tanmateix, per a Badia i Torró, aquestes vora 2.000 pàgines dels Estudis lingüistics $i$ culturals sobre «Curial e Güelfa» aporten «comptades novetats» (2014: 203) i no ofereixen la possibilitat de «construir una imatge articulada, contrastada i complexa de la situació que permeti d'establir cap forma d'hipòtesi global raonada» sobre el Curial (2014: 238). En el cas concret de la ponència de l'eminent dialectòleg Joan Veny, Badia i Torró sostenen que «no es poden acceptar les conclusions» que ofereixen relació amb «la valencianitat del Curial i del seu auton» (2014: 239). Les conclusions de Veny no encaixaven amb els seus esquemes.

La meua línia d'investigació i la meua interpretació del Curial parteixen d'un enfocament diferent als de Badia i Torró, sense restriccions ni apriorismes. Situen la gestació del Curial a Itàlia, on la situaven -quasi unànimement- altres experts en l'obra. Tracta d'explicar els suposats «misteris» $\mathrm{i}$ «rareses» del clàssic a partir del seu context italià. Busca identificar i confirmar en la història real les situacions i els personatges històrics de la ficció novel lesca. I, finalment, pretén oferir respostes documentades i argumentades a aquelles qüestions, entre les quals hi ha l'autoria o la transmissió de l’obra, que Badia i Torró (2010) consideren «pérdidas irreparables en las que es mejor no insistir».

\section{La reacció de Lola Badia i Jaume Torró}

La divergència d'objectius, mètodes i interpretacions del Curial anunciats en el meu article d'Estudis Romànics qüestiona seriosament la interpretació i la ubicació contextual de l'obra propugnades per Badia i Torró. Vist això, ambdós estudiosos han reaccionat amb insòlita immediatesa en diferents articles i declaracions de premsa. Extrac literalment algunes de les seues manifestacions, per tal que el lector valore com cal l'actitud intel lectual i la base argumental de les seues posicions davant la difusió de la meua proposta d'autoria: 
Abel Soler. L'atribució hipotètica de Curial e Güelfa a Enyego d'Àvalos (Consideracions sobre un «informe» de L. Badia i J. Torró)

* Badia: «Afirmar que Àvalos és l'autor de Curial e Güelfa es "un exercici gratuït, acientífic, partidari de la filologia-espectacle”» (declaració per a Ara.cat, Barcelona, 11/03/2017)

* Badia: «Molesta que una hipòtesi s'esbombi i se li doni una importància que no té» (Ara. cat, Barcelona, 11/03/2017)

* Badia: «Es poden fer aproximacions a l'època i a l'autor, però posar-li nom "és una ximpleria i és improcedent"» (Ara.cat, Barcelona, 11/03/2017)

* Badia: «La catedrática de la UB veu en la maniobra de la Universitat de València un pas més en l'obsessió per demostrar la valencianitat de Curial e Güelfa, "un ingenu propòsit d'apropiació provinciana", diu» (Ara.cat, Barcelona, 11/03/2017)

* Badia: «"Se trata de una filología-espectáculo", nos dice [Badia], y tilda de "deshonesta" y "fraudulenta" una tesis que, según la catedrática de la Universitat de Barcelona, está simplemente basada en el cruce de datos» (declaració per a La Vanguardia, Barcelona, 25/03/2017)

* Badia: «Dedicar más de cinco mil páginas a demostrar la valencianidad (adoptiva) del supuesto autor no tiene ningún sentido, si no es por un ingenuo propósito de apropiación provinciana» (La Vanguardia, Barcelona, 25/03/2017)

* Badia: «Nosaltres no hem llegit la seva tesi» (declaració aVilaweb, Barcelona, 05/04/2017)

* Badia: «Tots els arguments que [Soler] aporta són un joc, com si anessis muntant un trencaclosques i fessis un mica de trampa amb les peces» (Vilaweb, Barcelona, 05/04/2017)

* Badia: «El director de la tesi d'Abel Soler, Antoni Ferrando, que ara proposa D’Àvalos, fa poc que apostava per Joan Olzina, secretari del Magnànim, en un article d'Estudis Romànics» (declaració per a El Punt Avui, Barcelona, 16/03/2017)

* Badia i Torró: «Com Mark Twain quan va llegir la informació de la seva mort al diari, en aquest cas podríem dir que és una notícia molt exagerada» («Sobre l'autoria de Curial e Güelfa: una notícia molt exagerada», El Temps, Barcelona-València, 04/04/2017, pp. 62-63)

Culminen aquestes manifestacions amb un «Informe sobre l'atribució de Curiale Güelfa a Íñigo d'Ávalos», signat pels mateixos Badia i Torró, i autopublicat en edició electrònica en $<$ http://www.narpan.net/>, $<$ http://www.narpan.net/documents/InformeCurial.pdf $>,<$ http:/ /www.narpan.net/documents/ InformeCurialCastellano.pdf $>,<$ http://www.narpan.net/documents/InformeCurialEnglish.pdf $>$, i, posteriorment, a $<$ http://www.rmoa.unina.it/4551/>.

Segons declaren, l'informe, que no els ha sol licitat cap institució, «s'ha redactat per mirar d'evitar que la difusió com a certesa d'una hipòtesi sense fonament pugui alterar la descripció d'una obra important de la literatura medieval». Convé advertir que la meua hipòtesi, basada en dades i indicis molt fonamentats, no s'ha presentat mai com a «una certesa». El títol de l'article d'Estudis Romànics 
Abel Soler. L'atribució hipotètica de Curial e Güelfa a Enyego d'Àvalos (Consideracions sobre un «informe» de L. Badia i J. Torró)

es clou amb un interrogant. En el comunicat de l'IEC es presenta també com una hipòtesi, però es reconeix que, «si bé no hi ha cap document que certifiqui qui és l'autor de Curial e Güelfa, tal com passa amb quasi totes les obres medievals (...), segons Soler «hi ha poques obres que traspuin tantes dades sobre el seu autor com el Curial'». Altra cosa són les simplificacions amb les quals s'ha pogut divulgar l'atribució, eventualment, en algunes notes de premsa o en algunes publicacions periòdiques, el contingut de les quals no és responsabilitat meua.

Ara bé, entenc que els fonaments de la meua hipòtesi són tan sòlids, amb independència de qualsevol detall menor que puga ser corregit o matisat, que qüestionen seriosament la interpretació del Curial sostinguda durant anys per part de Badia i Torró. No és difícil intuir que els objectius de l'Informe de Badia i Torró persegueixen desautoritzar apriorísticament la hipòtesi d'autoria, així com desqualificar per endavant la mateixa tesi, malgrat haver declarat: «Nosaltres no hem llegit la seua tesi». Així ho reconeix sense embuts Lola Badia en entrevista concedida a Esperança Camps per a Vilaweb, Barcelona (5/04/2017). Vegeu: <http://www.vilaweb.cat/noticies/lola-badia-els-que-hem-treballatamb-el-curial-sabem-que-es-molt-dificil-fixar-ne-lautor-perque-no-hi-ha-cap-pista-material/>

Entenc que les discrepàncies interpretatives, tothora legítimes, s'haurien d'argumentar amb posterioritat a la publicació de la tesi. Però, donat que l'informe i les declaracions de Badia i Torró que l'han precedit incorren en inexactituds, en tergiversacions i prejudicis intolerables, m'he vist obligat a respondre formalment. Deixar de fer-ho hauria significat acceptar el que és inacceptable. Em limitaré als aspectes més rellevants, i deixaré per a la publicació de la tesi les referències bibliogràfiques i documentals pertinents.

\section{Els termes del debat}

\section{1. «Informe sobre l'atribució de Curial e Güelfa a Íñigo d'Ávalos»}

Aquest és el títol que Lola Badia i Jaume Torró han elegit per a l'informe. Ja d'entrada, ambdós historiadors de la literatura han alterat en Ínigo el nom d'Enyego, amb el qual es coneix Enyego d'Àvalos en la documentació cancelleresca en llengua catalana. Fins i tot quan s'adrecen a ell castellanoparlants com Alfons el Magnànim o el Príncep de Viana. Vegem alguns exemples: «Al magnífich don Enyego d'Àvalos, per les despeses que li ha conegut fer anant en Gènova, e de allí a Milà, hon lo dit senyor lo tramés per fets de la sua cort»; «Al magnífich e amat conseller nostre don Enyego de Dàvalos, locthinent de gran camarlench en lo regne de Sicília deçà Far»; «Lo rei d’Aragó: Don Enyego, recordeus-vos, stant en Milà e aprés, vengut a nós en Tíbuli, haver-nos scrit e dit de part de l'il lustríssimo duch...» de Milà, etc. Íñigo sols va ser per a Enyego d'Àvalos el seu nom de fonts i el que utilitzarà sobretot la historiografia castellana del segle XVI en avant.

El català fou la llengua d'adopció d'Enyego d'Àvalos, la dels seus col laboradors més acostats, a València, Milà i Nàpols, i la que, juntament amb l'italià, va transmetre als seus fills. I Enyego és el 
Abel Soler. L'atribució hipotètica de Curial e Güelfa a Enyego d'Àvalos (Consideracions sobre un «informe» de L. Badia i J. Torró)

nom amb el qual es va identificar en àmbit cultural catalanòfon, i no amb el que pretenen imposarli Badia i Torró. Així com solem respectar la voluntat d'un foraster quan decideix alterar la forma original del nom de fonts per a adoptar l'equivalent al país d'acolliment, així també crec que s'hauria de respectar la voluntat d'un exiliat com Enyego d'Àvalos, que assumí com a natural aquest nom d'acord amb els usos i codis idiomàtics de la terra d'acolliment inicial, València. Això no lleva que, independentment $i$ en la senectut, acceptara anomenar-se Inico, car s'havia italianitzat i havia vinculat el seu destí personal i el de la seua família, definitivament, al regne de Nàpols. Tractar-lo d'Ínigo, en castellà, en un informe redactat en català, no fa justícia a la documentació coetània, considerada la veracitat documental emanada de la cancelleria reial, ni s'ajusta a l'onomàstica personal de D'Àvalos, corrent en temps d'Alfons el Magnànim. No és difícil deduir allò que pretenen capciosament Badia i Torró: eliminar qualsevol connexió del més que probable autor del Curial amb la seua educació a València i amb la seua adopció del català de València com a llengua habitual i del català cortesà com a llengua de cultura literària.

Ja coneixem sobradament la manera que té Jaume Torró d'interpretar acomodatíciament els documents d'arxiu. A fi de situar la redacció del Tirant a Barcelona, atribueix la novel la a un Joan (esporàdicament, Joanot) Martorell «escrivà de ració» del Príncep de Viana, que era «ciutadà de València», però no cavaller, a diferència de l'autèntic autor del Tirant. No obstant això, assevera: «Ara podem afirmar amb seguretat que, després de la mort del Magnànim, Joanot Martorell no va tornar a València (...). Ara sabem que Joanot Martorell es movia en aquest ambient [l'entorn del Príncep de Viana, a Barcelona], i que va continuar entre les files de vianistes i antijoanistes fins més enllà de la mort del príncep» (2001: 111-112). El que sabem ara -amb certesa documental- és que pels anys 1460-1464 Martorell sí que va tornar a València i apareix en la cancelleria reial de Saragossa i en la batlia valenciana com un «cavaller habitador de la ciutat de València». Com sabem també, gràcies a un document inèdit publicat per nosaltres (Soler 2014), que l'any 1464 el cavaller Joanot Martorell, el del Tirant, estava precisament al servei de Joan II a Saragossa...

No hi ha cap document que relacione aquell «escrivà de ració» antijoanista amb el «cavaller» que havia escrit a València el Tirant abans d'anar a Saragossa. Allà on Torró elucubra sobre un presumpte ciutadà antijoanista de Barcelona, nosaltres documentem -amb proves tangibles- un cavaller de València i joanista. ¿A qui creiem, doncs: a Torró, o als proves arxivístiques ostensibles? Amb tot, Torró aprofita l'homonímia per tal que el Martorell providencialment «trobat» encaixe amb el seu apriorisme localista. Menysprea les ajustades puntualitzacions que ja li havia fet Agustín Rubio (2011) i ignora el criteri d'altres competents medievalistes com Antoni Furió, Mateu Rodrigo o Ferran Garcia-Oliver. No content amb això, silencia interessadament documents exhumats i publicats per Vera-Cruz Miranda (2011) sobre la casa del Príncep de Viana, perquè invaliden clarament la seua erràtica proposta d'identificació. L'aparent confusió involuntària deriva així en una manipulació ideològica de l'instrumental arxivístic, amb l'únic propòsit de situar la redacció del Tirant a la «cort de Barcelona». Ho proposa Torró en un article titulat «Una cort a Barcelona per a la literatura catalana del segle XV», on es presenta la gran descoberta. Abans d'ell, cap medievalista 
Abel Soler. L'atribució hipotètica de Curial e Güelfa a Enyego d'Àvalos (Consideracions sobre un «informe» de L. Badia i J. Torró)

-i no són poques les històries de la Catalunya medieval que s'han escrit, i de ben erudites!- havia aconseguit «troban» aquesta cort. Si existí tan esplèndida cort literària $-i$, per tant no és un miratge historiogràfic-, ¿com és que no s’havia dedicat abans cap monografia o cap tesi doctoral al seu estudi?

En aquest mateix article, Jaume Torró aplica a l'escriptor valencià Joan Roós de Corella un procediment d'«abducció» territorial similar al que pateix Joanot Martorell. Invocant un epistolari poètic entre Corella i el Príncep de Viana, Torró transforma Corella en un cortesà més de Barcelona, sense dubtes, i sense que hi haja ni un sol escrit, ni un sol indici documental que ho avale: «un escriptor lligat a la cort [del príncep de Viana a Barcelona], com correspon als gustos d'un príncep que s'agradava d'escriure en prosa d'art». Vist això, caldrà adoptar moltes precaucions en estudiar la història literària catalana del segle XV quan la descriuen -sobre fonaments més que dubtosos- Jaume Torró i Lola Badia.

\section{2. «[Al Curial] no hi ha cap referència a les terres de València» (Badia / Torró 2017b: 2)}

L'absència de referències explícites a València i el seu regne al Curial no exclou ni té per què excloure, en absolut, els vincles valencians de l'autor. Al Tirant, per posar un cas de comparança, a penes es troben aquestes referències explícites a València. I no per això es pot negar la valencianitat de l'autor, del text i del context d'escriptura.

Badia i Torró no han comprés que, darrere de quasi tots els noms històrics de ficció del Curial, hi ha evocacions de personatges reals, del temps de la ficció (segle XIII) i, sobretot, del temps d'escriptura (segle XV). Es percep a les clares que no són medievalistes. Amb uns coneixements elementals de la història de la noblesa valenciana del segle XV, sabrien que el personatge de ficció Pero Maça, també denominant alternativament en l'obra Pero Cornell, al ludeix indefectiblement al noble valencià Lluís Maşa o Cornell, fill de Pero Maşa, que alternava els cognoms per vincles hereditaris. Anton Espadaler ja ho va reconéixer honestament, malgrat que Pero Maça fou un dels grans trastamaristes valencians, i Espadaler havia apostat abans per un possible rerefons «urgellista» de l'obra.A Badia i Torró, la dada no els interessa pas: se silencia, i punt. Tampoc no els pot interessar saber, lògicament, que Lluís Maça-Cornell era cunyat d'Enyego d'Àvalos, per matrimoni amb una germana d'aquest, celebrat a València el 1426. Ho expliquen Zurita (XIII.40, V: 659) i altres referents de consulta bàsica. Ambdós cunyats eren companys al Consell Reial de la cort de Nàpols quan s'escrigué el Curial (Chilà, I: 369). Reconéixer-ho comportaria acostar-se massa a l'autor del Curial, que no no han sigut capaços ni d'intuir.

Badia i Torró (2011: 75) consideren que «la ciutat de Tunis i la seva horta mereixen l'única descripció de paisatge de tota la novel la», però ometen qualsevol referència al comentari de Ramon Miquel i Planas (1932: 524) a propòsit de la frase «alqueries e cases de les ortes», l'ús de la qual en el Curial «faría creure que l'autor, en la seva visió dels encontorns de Tunis, tingués present l'horta valenciana, més que no pas la de Barcelona, hont hi ha masíes, torres, etc., mes no alqueries». Alqueries és un arabisme general, és clar, però l'accepció i aclariment de «cases de les ortes» remet a un ús particularment viu a València. No sembla propi d'una pretesa edició crítica ignorar observacions com aquesta. 
Abel Soler. L'atribució hipotètica de Curial e Güelfa a Enyego d'Àvalos (Consideracions sobre un «informe» de L. Badia i J. Torró)

\section{3. «No hi ha cap pista material» sobre l'origen del ms. de la BNM i l'obra que conté (entrevista a Badia en Vilaweb, 05/04/2017)}

La pista material, perfectament tangible i analitzable, és el mateix Ms. 9750 de la BNE, còpia de mitjan segle XV relligada vers la fi del segle XV o primeries del XVI, amb uns makulatur fragments de documents administratius de la senyoria de Fuensalida- que condueixen, per mitjà d'estudis codicològics previs a la nostra tesi, a Toledo i a la casa dels Ayala (Ferrando 2012b). Badia i Torró es limiten a assenyalar l'existència d'aquests papers de rebliment de la coberta, com una curiositat, però sense referir-se per a res a aquestes constatacions materials: al contingut $\mathrm{i}$ a les seues possibles connexions amb el redactor del Curial. Interessa silenciar la prova. Davant d'això, el que fem ara és oferir una explicació hipotètica i versemblant sobre la conservació històrica del còdex, en base a informacions tècniques d'experts qualificats en paleografia i codicologia (Avenoza 2012; Sánchez 2012). Hem constatat que Enyego d'Àvalos i el seu germà Rodrigo eren parents directes de Pedro López de Ayala, senyor de Fuensalida, i que Rodrigo mantingué estrets vincles amb aquest. Simplement, establim un diàleg interdisciplinari entre diverses fonts d'informació empírica, científica, contrastable. Perquè la complexitat del Curial ho requereix.

D'altra banda, dues de les marques d'aigua del paper del manuscrit de Madrid contenen la Biscia Viscontea, emblema dels ducs de Milà. El paper amb aquesta marca podria haver viatjat a terres hispàniques, però és pràcticament desconegut ací. Més coses: la puntuació del manuscrit, que suscitava dubtes d'autenticitat en Jaume Riera (ell atribuïa el còdex a un falsificador del segle XIX) és la pròpia de molts manuscrits literaris italians de l'època. L'humanista Francesco Filelfo destacava elogiosament, per cert, que Enyego d'Àvalos era l'únic cortesà ibèric del rei de Nàpols que pautava els textos com els italians.

\section{4. «Si tu defenses que el Curialés un producte cortesà, no pots defensar alhora que és un producte marcadament dialectal» (entrevista a Badia per a Vilaweb, 05/04/2017)}

No conec cap filòleg expert que done per vàlida aquesta afirmació. En l'edat mitjana, una llengua cortesana és una llengua culta. És clar que sí, però no per això deixa d'acollir diatopismes. Prou que coneixen Badia i Torró que el Filocolo de Boccaccio, dedicat a una filla natural de Robert I de Nàpols, Maria, presenta nombrosos napolitanismes. I no per això deixarem de considerar-lo un escrit en llengua cortesana amb clars diatopismes. Però, quan el tema no interessa, el silencien. Amb Curial e Güelfa passa el mateix: el text literari, evidentment culte, conté repetides mostres d'un lèxic col loquial emprat preferentment o quasi exclusivament en terres de València. Es dedueix de les constatacions científiques d'eminents experts en lexicografia històrica, com són el català Joan Coromines (1954), el valencià Germà Colón (1973) o el mallorquí Joan Veny (2012). Badia i Torró, mancats de la més mínima competència en aquest camp, rebutgen sense arguments les conclusions dels lingüistes. Com no poden silenciar-les, les menyspreen, i avant. 
Abel Soler. L'atribució hipotètica de Curial e Güelfa a Enyego d'Àvalos (Consideracions sobre un «informe» de L. Badia i J. Torró)

Que les preferències lèxiques valencianes del Curial hagen de fer de la novel la cavalleresca un «producto marcadamente dialectal», o que representen - segons ells- «una apropiació provinciana» del clàssic català, són apreciacions poc serioses, d’ironia gratuïta i lamentable. Representen una burla a les aportacions d'eminents diacronistes.

\section{5. «Els llombardismes en qüestió no existeixen i, si existissin, no provarien l'autoria d'Íñigo d'Àvalos» (Badia / Torró 2017b: 13-17)}

Sorprén que aquells que no han publicat mai res sobre la «llengua llombarda»-així és com la denomina l'autor del Curial- dediquen la quarta part del seu Informe a comentar els possibles influxos que les parles septentrionals d'Itàlia -i, més concretament, la parla llombarda- pogueren haver exercit sobre l'idiolecte literari de l'escriptor. En l'edició de la novel la (Badia / Torró 2011: 114), ambdós agraeixen l'assessorament en matèria lingüística de Xavier Lamuela, que, com sabem, és catedràtic de Filologia Romànica. En canvi, en aquest Informe, s'autoerigeixen en experts en lingüística medieval.

Les petges de l'onomàstica i de la parla septentrional italiana (o de l'italià influït pel substrat llombard), i els referents geogràfics i culturals nord-italians presents en el Curial, són nombrosos. Sols l'acumulació d'indicis -Casalo per Casale; opció per Honorada, santa vinculada a Pavia; vitalitat de pretor enfront de l'extinció de l'ofici en altres llocs; un recurs als verbs sintagmàtics més acusat que en català, etc.- $\mathrm{i}$ no els exemples aillats, poden posar-nos sobre la pista d'un contacte de l'escriptor amb aquell escenari nord-italià, que també és -i no per casualitat o caprici- l'escenari preferent de la ficció curialesca.

Comentant el pas al Curial d'algunes errades d'Enric de Villena en la seua traducció glossada de l'Eneida, com pot ser l'aglutinació «Obsrea» per Ops i Rea, Badia i Torró (2011: 85), afirmen que «és rellevant haver pogut demostrar» que l'autor del Curial compartí aquesta errada amb el text de Villena, ja que la seua formació inicial s'hauria de relacionar amb «l'ambient cultural de les corts dels Trastàmares de les primeres dècades del segle XV». Insisteixen en l'observació (Badia /Torró 2015: 52) quan afirmen que «l'error conjuntiu que relliga el text del Curial amb l'exemplar glossat de l'Eneida sobre el qual treballava Enric de Villena en la seva traducció castellana, és una bella prova de la connexió de l'anònim amb l'ambient cultural de les primeres corts dels Trastàmara». També jo he pogut demostrar que l'estranya forma «subeumetria» del Curial s'ha de relacionar amb l'ambient cultural de la cort de Filippo Maria Visconti, duc de Milà, ja que aquesta errada de l'autor del Curial s'inspira en una mala lectura d'un terme copiat per Bartolomeo de' Bartoli en la seua Canzone delle virtù e dell scienže, manuscrit únic de la casa dels Visconti, ducs de Milà (Soler 2016). Entre altres «plagis», l'hàpax del Curial s'ha de relacionar amb la presència de l'autor de la novel la a la cort ducal milanesa. I l'únic catalanoparlant que tenia planer accés a la biblioteca familiar dels Visconti durant aquells anys fou el seu afavorit cambrer i, després, ambaixador d'Alfons el Magnànim a Milà, Enyego d’Àvalos (1435-1447). 
Abel Soler. L'atribució hipotètica de Curial e Güelfa a Enyego d'Àvalos (Consideracions sobre un «informe» de L. Badia i J. Torró)

Si apliquem els mateixos termes -la «bella prova»- que Badia i Torró apliquen a la connexió de l'autor amb el mestratge de Villena i amb la cort dels Trastàmara, la conclusió és evident: en el cas de Villena i els Trastàmara, qualsevol cortesà o ex-cortesà de València hauria pogut reproduir l'error textual; en el cas de la cort dels Visconti, la de «subeumetria» és una bella prova que ens porta directament a sospitar del comte de Monteodorisio, les armes heràldiques del qual són exhibides en tres ocasions en els primers capítols del Curial. La connexió intertextual no prova en absolut l'autoria d'Enyego d'Àvalos sobre Curial e Güelfa, però contribueix a determinar-la, quan l'entrellacem amb moltes d'altres.

\section{6. «Els arxius ja han estat molt treballats» (entrevista a Badia per a Vilaweb, 05/04/2017)}

Quan Esperança Camps pregunta a Lola Badia: «El fet que hi faltin les primeres planes, que l'obra no vaja signada, creieu que impossibilita l'atribució del Curial?», la professora respon: «Jo no sóc profeta. Els arxius ja han estat molt treballats». És una resposta insòlita en una recercadora el fet d'al legar que els arxius ja no poden oferir res més d'interés (que ella no sàpia de bestreta). És com si negara a altres l'aprofundiment en la recerca arxivística, i l'aportació de fonts novelles i esclaridores. Les «troballes» d'arxiu no són producte d'un do de profetitzar o d'una «il luminació», sinó de la constància i de moltes hores de treball dur. El que sembla insòlit d'entrada, s'aclareix quan sabem que Badia va declarar: «I, en història, no he fet arxiu. Quan vam editar Jordi de Sant Jordi, amb Riquer, vaig anar a comprovar tots els documents a l'arxiu, però no he fet recerca. He vist molts manuscrits, però els historiadors no em consideren un dels seus» (entrevista per a L'Avenç, 389, 2010, p. 20). Una història sense documents: vet aquí la seua brillant contribució a l'exhauriment interpretatiu dels arxius medievals de la Corona d'Aragó. Nosaltres també «hem vist» molts manuscrits del segle XV en el procés d'elaboració de la tesi. I els hem anat interrogant amb la calma necessària.

Per a Badia i Torró (2011: 55), «l'única via per a situar l'obra en la història de la literatura és prestar atenció a la cultura de l'Anònim que la va escriure, sobretot a la seva manera d'entendre el guiatge de Dante, Boccaccio i Petrarca». Això està molt bé, i és ben necessari. Tanmateix, i segons un enfocament com el meu, més ambiciós i més ampli, els convindria molt haver acudit complementàriament a fonts historiogràfiques. És molt convenient, en casos com el del Curial, acarar la documentació escrita i la bibliografia històrica amb les dades literàries, lingüístiques i culturals pertinents. Aquest és precisament el mètode que he aplicat al llarg de més de 5.000 pàgines, i que, contràriament a les seues afirmacions del 2011, ara comencen a reivindicar Badia i Torró (2017) en El Temps. «Es parteix d’una anàlisi exhaustiva dels indicis de tota mena presents a l'obra: culturals, contextuals, geogràfics, lingüístics, etc. Un cop ben estructurat el canemàs, es mira si quadra amb alguna figura real». Badia i Torró, malgrat l'anàlisi minuciosa de l'obra que han intentat fer, han sigut incapaços d'avançar en la contextualització correcta de l'obra o de formular ni tan sols una hipòtesi d'autoria a partir de les dades que manejaven. La tasca ja s’ha fet com ells la volen. Està conclosa i en premsa. Qüestionar-la sense conéixer-la és poc ètic.

Cal reconéixer que una part de la «veu de l'Anònim» s'expressa, efectivament, per boca del personatge Melchior de Pando (o de Pandó), tresorer de la Güelfa, d’uns cinquanta anys. Però no 
Abel Soler. L'atribució hipotètica de Curial e Güelfa a Enyego d'Àvalos (Consideracions sobre un «informe» de L. Badia i J. Torró)

tota. El Curial difícilment pot ser la «crònica» d'un tresorer, com proposen Badia i Torró. No hi ha res del que afirmen en aquest sentit que estiga avalat per cap document (Badia / Torró 2011: 44): «Tot el que sabem de l'Anònim es que hauria pogut nèixer pels volts de 1400». Si l'autor és Enyego d'Àvalos, com propose, aquest era un cavaller de poc més de trenta anys quan va escriure el Curial. Hi ha, a més a més, raons poderoses per a proposar que l'autor s'expressà en la novel la a través de múltiples manifestacions. També ho va fer a través del protagonista de la seua ficció, Curial. Una part de la biografia de D’Àvalos troba reflectiment especular en el bibliòfil cavaller de la ficció.

\subsection{La novel ta Curial e Güelfa «fue escrita en un ambiente ibérico relacionado con las cortes de los Trastámara» (Badia / Torró 2010: 44).}

No es coneix cap document que puga avalar aquesta contundent -i equivocada- afirmació de Badia i Torró, que situa el Curial a la Península Ibèrica. Ho reiteren en tots i cadascun dels seus treballs d'aproximació o divulgació. Com quan diuen que la «consciència literària de l'Anònim (...) connecta amb l'ambient cultural ibèric de les corts dels Trastàmara» (Badia / Torró 2015: 56). No reconeixen, ni explícitament ni implícitament, les orientacions dels Estudis lingüistics i culturals sobre el Curial (2012), que els obligaven ja a matisar algunes conclusions. Ara bé, fa poc, Badia (2016: 186) es va veure obligada a suprimir tot allò de la gestació del Curial en l'«ambient cultural ibèric» i a afirmar: «L'anonimo autore, di cui si ignora nome e contesto -questo è il grande mistero del Curial e Güelfa».

En el seu Informe del 2017, Badia i Torró, davant les evidències del meu article d'Estudis Romànics, s'afanyen a rectificar el «grande mistero» $\mathrm{i}$ admeten preventivament que l'obra, en efecte, deu ser un «producte d'una cort internacional, la d'Alfons el Magnànim», és a dir, el Nàpols on residia D'Àvalos. Per a arribar a aquesta conclusió no cal faltar a la veritat: «Soler situa l'autor a la cort napolitana d'Alfons el Magnànim, tal com (...) s'ha demostrat en un article de M. T. Ferrer de 2011 i en l'última edició crítica de l'obra (ed. L. Badia i J. Torró, Barcelona, 2011)». Certament, l'article de Ferrer i Mallol sí que apuntava cap a Itàlia, o cap a Savoia, com a lloc d'escriptura, i vinculava clarament -i documentadament, amb escrits d'arxiuel contingut de la ficció amb el Nàpols on residien D'Àvalos i Sescases. Tanmateix, en la Introducció de l'edició 2011 de Badia i Torró, i en la presentació que fan ambdós del Curial en la Història de la literatura catalana (2015), tan solament fan referència a l'«ambient cultural ibèric de les corts dels Trastàmara». A penes hi esmenten el nom d'Itàlia, i ni tan sols tenen en consideració la recerca de Ferrer i Mallol, que ara tant reivindiquen. Qualsevol lector o recercador pot comprovar de visu l'abast de la fal làcia.

\subsection{La del Curial és «una cultura pròxima a l'humanisme que ha dibuixat, finalment, l'ambient de la cort del Magnànim» (Badia / Torró 2017b: 3)}

Són molts els articles de Júlia Butinyà de les dècades del 1990-2000 on s’insisteix en l'influx de l'humanisme italià sobre la cultura literària de l'autor del Curial, lògicament en àmbit napolità (vegeu alguns treballs seus en <https://dialnet.unirioja.es/servlet/autor?codigo=2542727>). Ho confirma el títol mateix de la seua monografia compilatòria, Tras los orígenes del humanismo: «Curial e Güelfa» (1999, 1a. ed.). Doncs bé, ni en la Introducció a l'edició del 2011, ni en altres estudis recents, Badia i Torró 
Abel Soler. L'atribució hipotètica de Curial e Güelfa a Enyego d'Àvalos (Consideracions sobre un «informe» de L. Badia i J. Torró)

dediquen un sol epígraf a les idees de caràcter humanístic que fan del Curial un text més interessant del que ells mai han sigut capaços d'arribar a comprendre, pel seu relatiu desconeixement de la cultura literària del Quattrocento. En la «Introducció», s’al ludeix molt de passada, anecdòticament, a Nàpols i a la cort napolitana del rei Alfons d'Aragó. La desorientació es palesa en la imatge elegida per Badia i Torró per a il lustrar la coberta de l'edició curialesca del 2011. Es tracta d'un cavaller de la Catalunya profunda, icona treta d'un retaule gòtic de Lleida. Potser no és la més idònia per a una obra protagonitzada per un elegant cortesà italià, i relacionable amb ambients de renovació humanística propis del Quattrocento. El resultat editorial resulta desconcertant, i contradiu obertament el context italià i napolità de l'obra, que ara diuen ells que ha descobert «finalment».

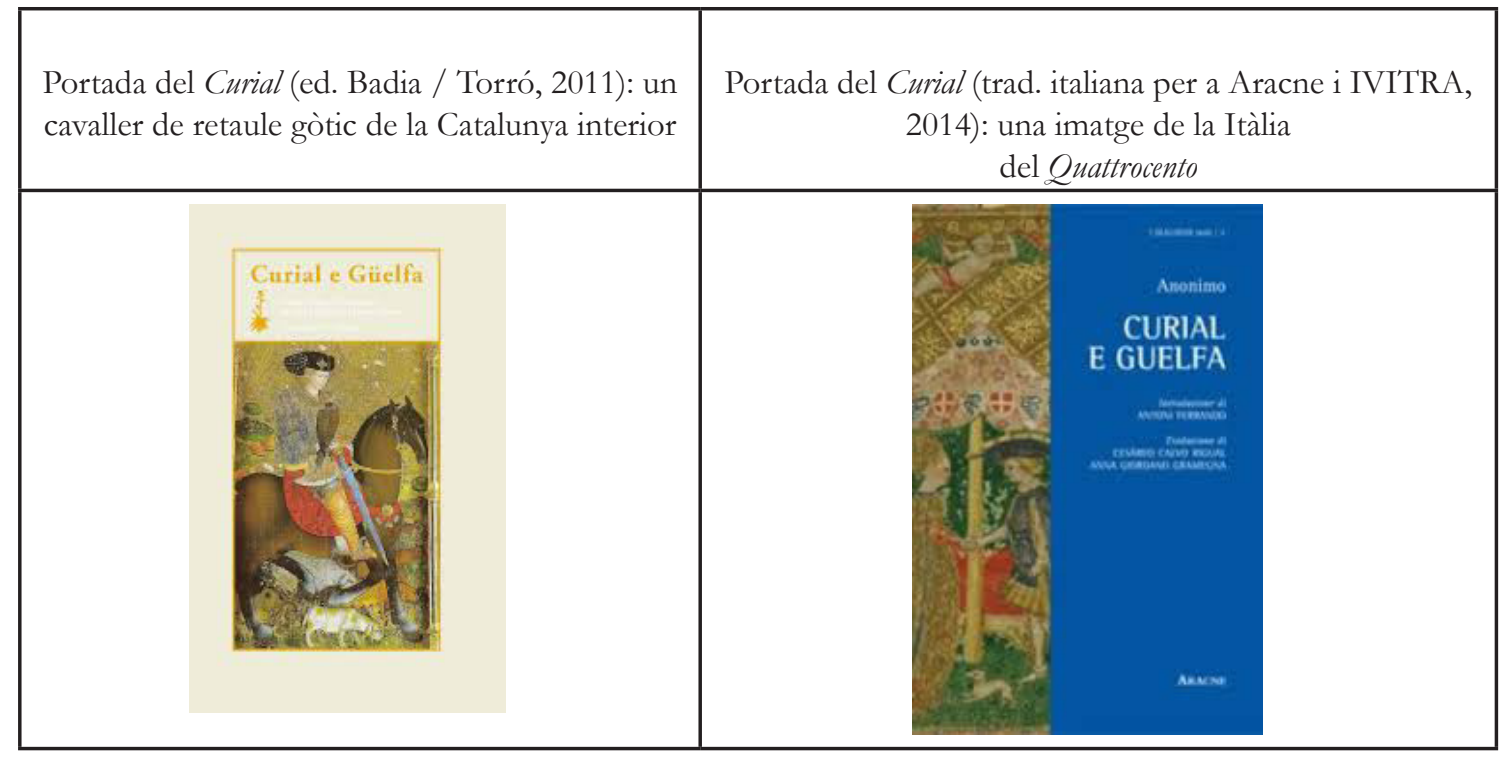

Resulta sorprenent que Badia i Torró, «finalment» i precisament en el seu Informe sobre la nostra tesi -que recordem que diuen que encara no han llegit-, renuncien tan ràpidament a les «corts ibèriques» $\mathrm{i}$ als retaules gòtics per a assumir com a descoberta pròpia i extraordinària el context napolità i filohumanista del Curial. Tot això no és cap novetat. Ho havien proposat i provat abans que nosaltres altres estudiosos de reconeguda solvència (Butinyà 1999; Ferrando 2007, 2012). Si es consulten els darrers articles sobre el Curial de Badia i Torró, anteriors als meus dels anys 20152017, es comprovarà fàcilment que mai no parlaven d'«una cultura pròxima a l'humanisme que ha dibuixat, finalment, l'ambient de la cort del Magnànim». Subratllem i celebrem, doncs, la claudicació adverbial. Quins autors han precisat, finalment, l'ambient napolità? ¿I qui s'ho vol atribuir ara, després d'haver errat durant anys... i d'haver contribuït al foraviament de professors i lectors?

Pot ser que llur desenfocament contextual, esmenat finalment amb la meua tesi, provinga d'algunes orientacions donades per Badia des del 1987 als seus possibles lectors. Aleshores considerava «incongruències» $\mathrm{i}$ «pintoresquismes» alguns decorats iconogràfics i mitològics del Curial, i veia 
Abel Soler. L'atribució hipotètica de Curial e Güelfa a Enyego d'Àvalos (Consideracions sobre un «informe» de L. Badia i J. Torró)

en l'autor un escriptor qui sap si animat per «un cert aire esotèric (...), o més brutalment, pensar que la ignorància del nostre anònim no donava per a més» (Badia 1987 [1985]: 175). El judici -o el prejudici intel lectual- diu molt del distorsionador enfocament epistemològic practicat en segons quins àmbits de la crítica literària.

\section{9. «L'article [d'Estudis Romànics] presenta errors de mena diversa» (Badia / Torró 2017b: 4)}

Resulta sorprenent que Badia i Torró comencen el seu Informe cercant «errors» en el nostre article i incórreguen ja en tals errors d'entrada, quan diuen: «Cap expert no parlaria d'una cort napolitana abans que el rei Alfons prengués Nàpols el 1442». Si hagueren adquirit un mínim coneixement del regnat d'Alfons el Magnànim, sabrien que aquest es proclamà rei de Nàpols el 1435. En gener del 1436 establí la seua cort a Gaeta, la segona ciutat més important del Regnum Neapolitanum. Hi hagué cort napolitana del rei d'Aragó, en conseqüència, des del 1436, i així ho solen considerar els medievalistes.

Més sorprenent és que ignoren que Enric de Villena i el Marqués de Santillana foren cortesans actius d'una València on residien Alfons el Magnànim i Joan de Navarra. Santillana no «se'n passà» a l'obediència castellana fins a vespres de la guerra del 1429 (Zurita XIII.52; V: 699 i 702). El mateix Enric instal là la seua famosa biblioteca durant un temps a València, com indica en la seua correspondència privada, i deixà una filla il legítima criant-se a la cort valenciana: la futura escriptora sor Isabel de Villena.

Convindria documentar-se millor sobre aquestes i altres qüestions. El primer cas comentat indica que fins ara no prestaven gaire atenció al context napolità del Curial e Güelfa. El segon cas indica que tampoc no coneixen bé una d'aquelles «cortes ibéricas de los Trastámara» que tant han invocat sense explicitar-ne el nom: la cort de València, on residí preferentment Alfons el Magnànim del 1416 al 1430, i on s'educà Enyego d'Àvalos.

\subsection{0. «Aquests diccionaris [esmentats al Curial] són els més corrents arreu» (Badia / Torró 2017b: 5)}

La coincidència exacta entre els diccionaris citats en el Curial per l'autor i els disponibles a la cort i ciutat de Milà (vegeu Pedralli, 2002: 171) no resulta gens suggerent per a Badia i Torró, perquè «són els més corrents arreu». Ignorem a quin marc geogràfic es refereixen amb l'adverbi «arreu», però ens consta que la llista del Curial no troba correspondència amb les de Florència (documentades per Christian Bec), Nàpols (Tammaro de Marinis, José Trenchs Odena, Xavier Gómez Font), Sicília (Henri Bresc), Mallorca (Jocelyn N. Hillgarth) o Castella (Karl Kohut). Les Derivationes d'Uguccione, per posar un cas, no eren fàcils de trobar fora del nord d'Itàlia. La correspondència exacta del Curial amb els manuals emprats a Milà es documenta amb precisió, i en base a inventaris concrets. Badia i Torró es basen únicament en una bibliografia generalista. En realitat, amb les seues observacions, solament tracten de restar valor a l'evidència documental que aporte en una tesi que desconeixen, malgrat haver estat oberta a la consulta de la comunitat científica el passat mes d'octubre. De pas, tracten de negar la vinculació de l'autor del Curial amb Milà. 
Abel Soler. L'atribució hipotètica de Curial e Güelfa a Enyego d'Àvalos (Consideracions sobre un «informe» de L. Badia i J. Torró)

\subsection{1. «El lleó rampant de Curial, ni té res a veure amb Íñigo d'Ávalos ni prova res sobre l'autoria de l'obra» (Badia / Torró 2017b: 7)}

En les primeres pàgines del Curial apareix descrit amb gran detall, i es reitera aquest detall descriptiu tres vegades consecutives: Curial enarbora en llaor de la seua promesa, la Güelfa, un estendard partit en dos campers heràldics, amb un lleó rampant que els travessa. Es pot posar en dubte que es tracte d'una signatura heràldica de la novel la per part de l'autor, però el que no pot posar-se en dubte és la correlació cronològica dels fets:

[1] Enyego d'Àvalos, compromés des del $1443 \mathrm{amb}$ Antonella d'Aquino (aleshores, d'edat infantil), va passar a ser lloctinent (1444) de l'avi d'aquesta, el gran camarlenc Francesco d'Aquino, a qui reemplaçava de facto. Badia i Torró no haurien de confiar en històries locals obsolescents o en enciclopèdies poc actualitzades a l'hora de documentar-se. Els convindria molt recórrer a fonts arxivístiques de primera mà; a publicacions historiogràfiques solvents i actualitzades, preferiblement universitàries. $\mathrm{O}$, en defecte d'aquestes, a les ressenyes de la col lecció Fonti Aragonesi. Solament així podrien opinar amb un fonament una mica més sòlid. Les fonts que jo empre coincideixen amb les de l'historiador italià Raffaele Colapietra, que ha estudiat durant anys, i rigor i amb el degut suport arxivístic, bibliogràfic i genealògic, la vida i família d'Enyego/Inico d'Avalos. Citem-lo, doncs, en la síntesi de dades que ofereix en una de les seues publicacions més actualitzades (2013: 15-16). El subratllat (que anul la les elucubracions cronològiques de Badia i Torró) és nostre :

\footnotetext{
È questa [de camarlengo] infatti la dignità ben nota con cui Innigo [d'Avalos] appare in Masuccio, un ufficio che gli veniva attraverso Antonella d'Aquino, sua fidanzata nel 1443 e consorte nel 1452, il cui nonno Francesco, conte di Loreto e principissimo tra i fideles di Alfonso, gli aveva ceduto la luogotenenza nel 1444, e cinque anni più tardi, alla sua morte [1449], la titolarità nell'ufficio del camerlengato ed in uno dei suoi feudi minori, la contea di Monteodorisio.
}

[2] La concreció i la consumació del matrimoni entre Enyego i Antonella s'efectuà el 1450 i el 1452, respectivament, quan la contraient accedí a l'edat núbil. Però tothom sabia a la cort de Nàpols, i així ho recullen les cròniques, que els Aquino havien promés l'any 1443 a Enyego d'Àvalos la donzella i, a manera de dot, el comtat de Monteodorisio, associat a l'heràldica del lleó que travessa els dos campers. Els D'Àvalos i els D’Aquino encara van reforçar més aquesta aliança, el 1447, amb un nou enllaç nupcial: el de Beatriu d'Àvalos i el germà major d'Antonella. A més, entre el 1443 i el 1452, el compromís amb Enyego donà lloc a un sonat contenciós amb la tia d'Antonella, una viuda posseïdora del comtat, d'una banda, i els D'Aquino i els seus interessats aliats, els D'ÀvalosGuevara. En comptes de fiar-se d'una història local del 1942, Badia i Torró haurien d'haver acudit a fonts de primera mà i a cròniques de testimonis directes, com Loise de Rosa (1998: II,522) i haurien comprovat que allò que ells denominen la «donació» del comtat no fou tal donació, sinó una mena d'«usurpació» encoberta per la via judicial. L'apropiació la tramà el rei Alfons per a beneficiar amb un gran feu Enyego d'Àvalos: el feu del lleó rampant. 
Abel Soler. L'atribució hipotètica de Curial e Güelfa a Enyego d'Àvalos (Consideracions sobre un «informe» de L. Badia i J. Torró)

[3] S’equivoquen, a més, Badia i Torró, quan sostenen que, fins el 1472, aquest lleó rampant no formava part de l'heràldica del matrimoni D'Àvalos-D'Aquino. De facto, els D'Aquino reivindicaven Monteodorisio com a dot per a la promesa d'Enyego des del 1443. I, amb el comtat, anava l'escut de la perjudicada tia, unit a la senyoria per vincle testamentari. El que succeí el 1472 és que Antonella heretà els feus dels D’Aquino, comtes de Loreto, i quartejà les armes dels D'Aquino (bandes d'or i de gules) amb el lleó de Monteodorisio prèviament adquirit (Enyego era conegut com «il conte di Monteodorisio»). Evidentment, qui oïra recitar el Curial cap al 1448-1450 a la cort de Nàpols, just abans que Enyego d'Àvalos consumara el seu matrimoni amb Antonella d'Aquino, tindria ben clar de quin lleó «naixent» (figura heràldica poc comuna: aquell que travessa dos campers) es tractava. No eren les armes de la seua muller encara, però sí -com en la mateixa ficció curialesca- les de la seua rica promesa, l'adolescent i imminent comtessa de Monteodorisio.

En qualsevol cas, i deixant de banda el material erudit, una imatge, mal que siga d'unes dècades després, pot il lustrar més que mil vocables:

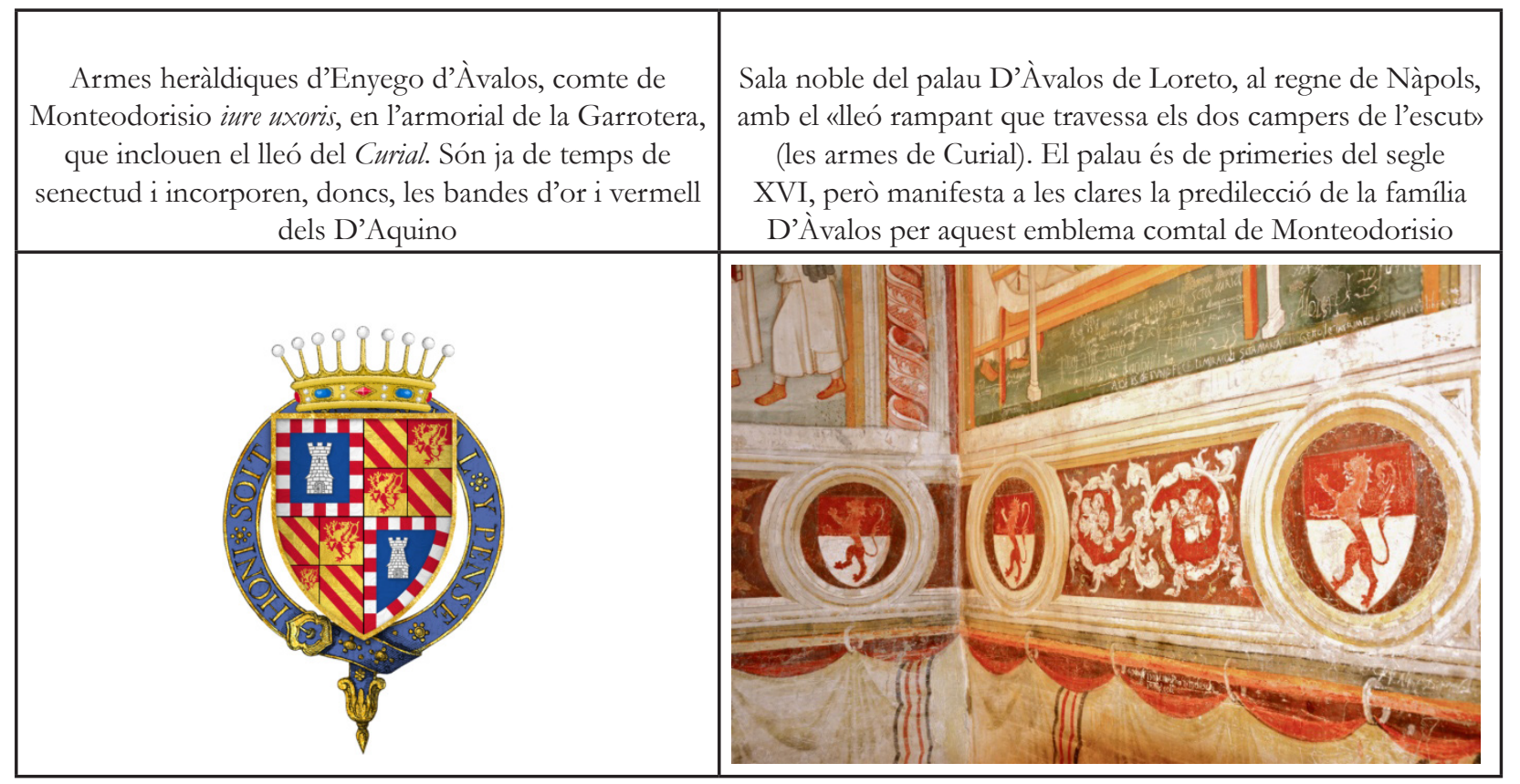

Badia i Torró declaren haver dedicat «trenta anys d'investigació (...) a la comprensió de l'obra i de la cultura de l'Anònim», però, amb aquest bagatge i dedicació, han estat tostemps incapaços d'oferir qualsevol hipòtesi d'autoria del Curial alternativa a les ja conegudes. Per no parlar d'interpretar adequadament aquesta i altres insígnies heràldiques. En el segle XV, els blasons d'armes revelaven i exposaven la identitat dels posseïdors, en indumentària, mobles, joies, llibres, etc. Ells, encara que no ho reconeguen ni ho ho vullen reconéixer explícitament, s'han adonat que el lleó rampant 
Abel Soler. L'atribució hipotètica de Curial e Güelfa a Enyego d'Àvalos (Consideracions sobre un «informe» de L. Badia i J. Torró)

del Curial té molt a veure amb Enyego d'Àvalos i que és un indici quasi determinant sobre la identitat d'aquell que escrigué el Curial. Els dol precisament que haja vingut «un altre» aportant una conclusió tan evident. I els resultarà complicat, és clar, admetre l'evidència. Si tot el que fins ací s'ha exposat no haguera resultat inconfessablement esclaridor per a ells, no s'haurien precipitat a difamar apressadament i a impugnar la nostra hipòtesi d'atribució per periòdics i xarxes socials. Simplement, l'hagueren ignorada i silenciada, com han fet amb els treballs d'altres investigadors solvents: Aramon, Butinyà, Ferrando, Mesa Sanz, Sònia Gros o la prestigiosa medievalista M. Teresa Ferrer i Mallol, les aportacions de la qual -fonamentals per a orientar la nostra recercaconsideraven irrellevants. Ara les reivindiquen...

\subsection{La medalla del Pisanello «no serveix per sustentar la seva hipòtesi [de Soler] d'atribució [del Curial a Enyego d'Àvalos]» (Badia / Torró 2017b: 8-10)}

Badia, Torró i jo mateix coincidim en la interpretació de la divisa d'Enyego d'Àvalos (revers de la medalla del Pisanello, Nàpols, 1449) com un escut simplificat d'Aquil les, opció iconogràfica constatada per fonts italianes del segle XVI relacionades amb la família. Ells ho atribueixen a un coneixement per part de l'autor del Curial del cant XVIII de la Ilíada en la versió que Alfons el Magnànim encarregà a Lorenzo Valla en la dècada del 1440. La representació s’inspira en realitat en la descripció que ofereix la Ilias Latina. Aquesta facilita l'esquematització iconogràfica que precisa el format en miniatura de la medalla, encara que modificada -segons el nostre criteriper a representar Tebes i el Parnàs, la seu de les Muses. Fins ací els matisos sobre la font literària tinguda en consideració.

Ara bé, discrepem sobre altres aspectes. Per a Badia i Torró, la relació de la medalla d'Enyego d'Àvalos (que s'autotitulava «amatore delle Sacre Muse») amb el Parnàs, deriva d'un commento de la Comèdia de Dante, que, a més, és una font bàsica del Curial. Per a mi, és realment el motto o missatge «per vui se fa» el que desvela la relació, com era corrent en la «micropoética de las invenciones» (Deyermond) que acompanyava aquestes divises. El mot va unit a rams de roses i es presta a una lectura enigmàtica i ambigua. Es pot llegir en català ('es fa pel dia d'avui'), en commemoració de l'elevació de D'Àvalos a gran camarlenc de Nàpols, o en italià ('per vosaltres [les Muses: les roses de Pièria] es fa'). Aquestes mateixes Muses «colents Helicona» presideixen el proemi al llibre III del Curial.

En tot cas, és evident que la interpretació de Badia i Torró pretén excloure qualsevol relació d'Enyego d'Àvalos amb el contingut de la novel la cavalleresca Curial e Güelfa. Objectivament, no és una interpretació més encertada que la nostra proposta.

3.13. «Com que el manuscrit és indubtablement una còpia, les suposicions del viatge [del còdex] a Toledo deixen de tenir validesa per a l'establiment de l'autoria de l'obra» (Badia / Torró 2017b: 10-11)

Sens dubte, el viatge del còdex del Curial d'Itàlia a Toledo és un fet deduible lògicament (paper italià $>$ text català $>$ coberta toledana), però el fet que siga una còpia no exclou una més que 
Abel Soler. L'atribució hipotètica de Curial e Güelfa a Enyego d'Àvalos (Consideracions sobre un «informe» de L. Badia i J. Torró)

possible relació de l'autor amb Toledo. Es tracta d'un aspecte que contribueix raonablement a explicar la procedència del manuscrit. Sostenir que una còpia coetània de la del text original no té cap relació amb l'entorn de l'autor és poc raonable; més encara quan aquesta còpia és l'única subsistent i quan no hi ha cap notícia documental més sobre el Curial en inventaris bibliogràfics. Tan sols pretenen desautoritzar gratuïtament una hipòtesi que desbarata la major part del seus plantejaments anteriors sobre l'obra literària.

L'intent de negar l'evidència relativa a les marques del paper o filigranes impreses en els diferents plecs del Curial s'inscriu en el mateix discurs manipulador. No és una sola, sinó tres de les sis les marques d'aigua, les que ajuden a traçar una intersecció codicològica. Tot ens duu a la cort de Milà pels anys 1438-1452 molt aproximadament. I fou just aleshores quan s'escrigué la novel la. Observem el gràfic:

1

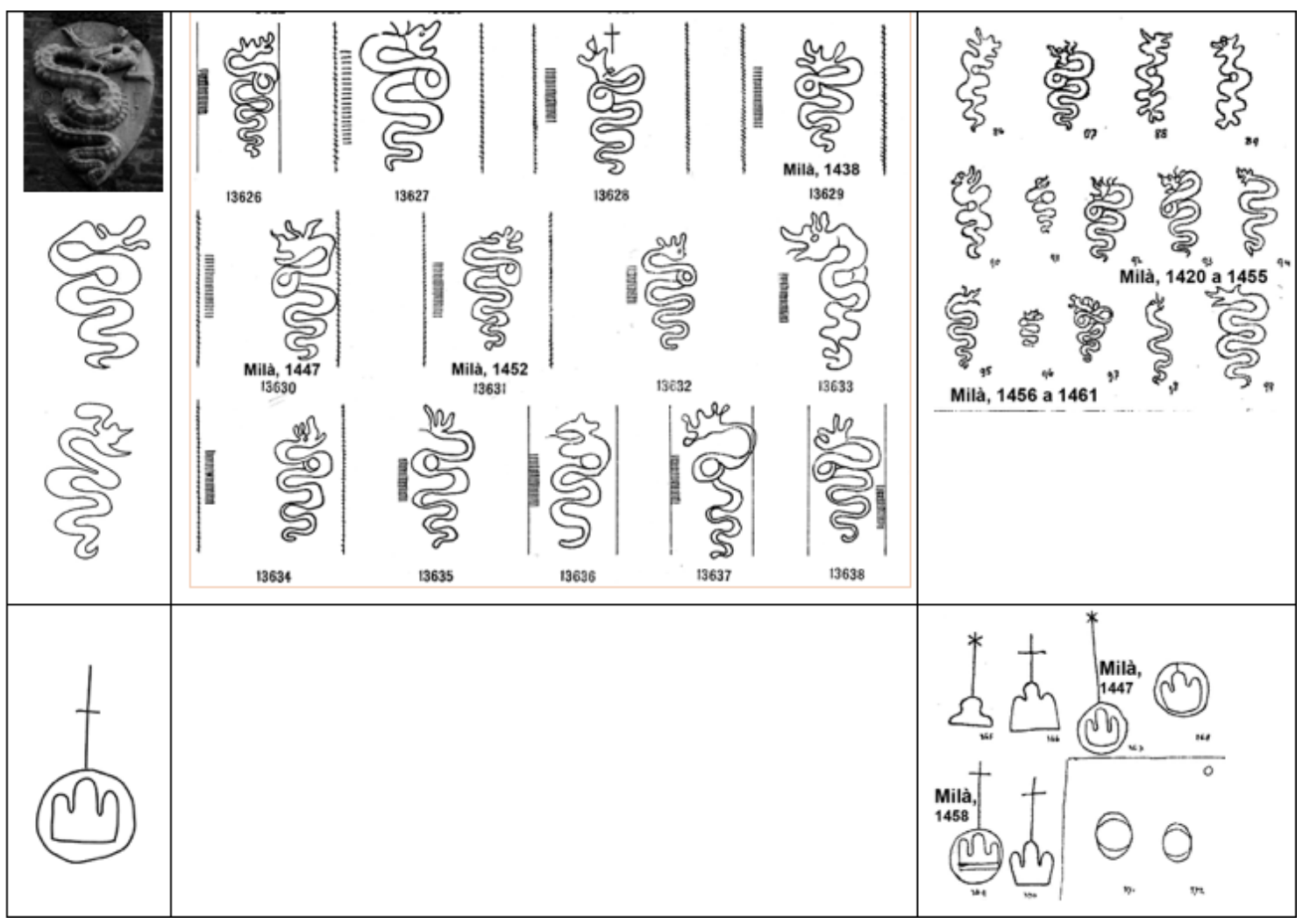

1. Filigranes del Curial (Avenoza, 2012)

2. Briquet (1966; catàleg d'àmbit europeu)

3. Monneretde Villard (1954-1956; Archivio di Stato i altres de Milà) 
Abel Soler. L'atribució hipotètica de Curial e Güelfa a Enyego d'Àvalos (Consideracions sobre un «informe» de L. Badia i J. Torró)

«El paper viatjava en el segle XV». És clar que sí. Ara bé, fer viatjar diferents raimes de paper blanc milanés, amb distintes marques i qualitats, a milers de quilòmetres de distància (posem que a «les corts ibèriques dels Trastàmara», on Badia i Torró proposen l'àmbit del Curial), i que després coincidisquen totes en un mateix escriptori, i que a continuació vinga a dit escriptori el copista del Curial buscant específicament papers milanesos per a cosir-los en un sol volum, és ben difícil. Com a hipòtesi explicativa, sembla una mica desgavellada. ¿No és més fàcil deduir que el procés de «reunió» en un sol volum de diferents sobres de paper llombard es va produir a la mateixa ciutat de Milà? O prop d'allí?

\subsection{4. «Després hi ha aquesta idea de fer passar D’Àvalos de Toledo a València i valencianitzar el Curial. Noi, valencianitzar el Curial costa molt que algú s'ho cregui» (entrevista a Badia en Vilaweb, 05/04/2017)}

No sembla propi de persones que es proclamen «medievalistes» ignorar els testimonis de Zurita i altres cròniques on es documenta fàcilment el procel lós trasllat i la presència del conestable Dávalos i els seus fills a València des del 1422, o l'enllaç familiar d'aquests amb els Maça-Cornell el 1426. També hi ha documents de l'Arxiu de la Corona d'Aragó que fan seguiment d'aquesta presència, o uns altres escrits inèdits que aportem en la nostra tesi, de notaris de l'Arxiu de Protocols del Patriarca (València). Tot plegat és redueix, segons Badia, a una suposada «idea de fer passan» els Dávalos de Castella a València i a Nàpols. Ningú no els hi fa passar. Realment, hi passen. És poc ètic que se'ns acuse d'haver treballat, no amb documents històrics i testimonis fefaents i tangibles -a més de cròniques conegudíssimes-, sinó a partir d’una «idea», preconcebuda no se sap amb quina fosca intenció.

No conec ningú que haja pretés «valencianitzar» Curiale Güelfa, expressat així. Els experts s’han limitat a constatar la presència de preferències lèxiques valencianes en l'obra. I això és tot. Joan Coromines, l'any 1954, ja anotava que el Curial era una novel la dialectalment suggerent, «cuyo léxico parece sugerir un autor valenciano». Germà Colón, en un treball del 2011, constatava que el lèxic «apunta clarament a València». Joan Veny, el 2012, comenta que l'obra conté «massa elements propis per a posar en dubte la valencianitat de l'auton». Per a Badia i Torró, en canvi, l'estudi de Veny, ara reiterat en «Curial e Güelfa i el valencià» (2017), els sembla inacceptable. El rebutgen perquè contradiu la seua línia de recerca, i no s'ocupen ni d’al legar arguments científics; tan solament prejudicis.

Desqualificar els estudis realitzats en profunditat pels nostres principals especialistes en lexicografia diacrònica per part d'aquells que no ho són ni pretenen ser-ne, sembla una mica deshonest. Badia arriba a afirmar, respecte de Veny i altres, que li causa «angúnia portar la contrària als especialistes». Dit altrament: Badia i Torró creuen que només ells estan en possessió d'una ciència i una veritat inalterables $\mathrm{i}$ immunes a la controvèrsia científica. Recordem que, quan els medievalistes van posar en dubte la foraviada identificació de Joanot Martorell amb un ciutadà trinxant que tenia fills, Torró va respondre amb un article titulat: «Només hi ha un Joan Martorell documentat amb el nom de Joanot» (2012). Es tracta d'una asseveració que qualsevol medievalista que freqüente els arxius 
Abel Soler. L'atribució hipotètica de Curial e Güelfa a Enyego d'Àvalos (Consideracions sobre un «informe» de L. Badia i J. Torró)

trobaria irrisòria. A Badia i Torró, poc els importa que el consens acadèmic sobre les preferències lèxiques de la novel la siga rotund: el Curial és diatòpicament un text catalano-occidental, i molt probablement valencià (Colón 1985, 2011; Veny 2012, 2017; Ferrando 2007, 2012). Atesa la meua formació de medievalista, si tots els lingüistes, els experts, insisteixen en el lèxic valencià, la meua comesa no pot passar sinó per assumir-ho, reflectir-ho i tractar d'explicar-ho des d'una perspectiva històrica (i biogràfica, és clar, una vegada comprovat que l'autor podria ser algú com Enyego, criat a València).

Si es donen diferències de matís entre els lexicògrafs ara citats, aquestes no afecten l'anàlisi lingüística, sinó que afecten a la seua posició sobre l'homologació entre el color diatòpic de l'obra ila procedència geogràfica de l'autor. Antoni Ferrando (2012) precisava que «la coloració valenciana que presenta el lèxic del Curial, reconeguda pels més prestigiosos lexicògrafs, no comporta necessàriament una procedència del mateix origen [és a dir, que l'autor fóra un valencià de naixement], però sí almenys una vinculació [amb València] molt directa». Colón, després d'oferir una «llista de lexemes que tenen traça de ser únicament o preferentment valencianes», ja va remarcar oportunament: «El Curial, vist el seu component lingüístic, ha de ser valencià, o si més no de les terres ponentines» (2011: 287-288). Els dubtes de Colón sobre «la procedència de l'autor» no es basen en el lèxic, que ell defineix com a valencià, sinó en la presència d'alguns catalans en l'obra i en la «total absència de València» en la ficció curialesca (Colón 2011: 290). Dubta de l'origen valencià de l'autor, però no de les preferències lèxiques valencianes del text. Tanmateix, Badia i Torró (2015: 99) tergiversen el que diu Germà Colón. Descontextualitzen interessadament una citació, i li atribueixen fal laciosament aquesta suposada conclusió: «tècnicament no es pot emetre un judici fonamentat sobre la coloració dialectal del Curial (Colón 2011: 290)».

I encara afigen, com si fóra qüestió de fe i no de lingüística: «Noi, valencianitzar el Curial costa molt que algú s’ho cregui...». Ningú no ha valencianitzat el Curial, dita així la cosa. Lèxicament, el Curial és allò que és, i no allò que creiem o que voldríem que fóra. No obstant això, observem com Badia i Torró han «barcelonitzat» parcialment la llengua del Curial en l'edició del 2011, sota el pretext d'una modernització gràfica que permetrà una millor «interpretació» de l'obra. Mantenen almàguena, bambollats, traure, etc., però substitueixen arrancar, febra, jagant, malair, maravella, sancera, etc. (formes preferentement catalano-occidentals o valencianes), respectivament, per arrencar, febre, gegant, maleir, meravella, sencera, etc. (formes preferentement barcelonines). Parlen després d'un autor que potser «esborrés o diluís les expressions i els recursos marcats geogràficament per tal d'aconseguir una elegant indeterminació dialectal». Deuen referir-se, no a l'autor, sinó al que ells mateixos han esborrat i diluit per afer encaixar l'obra en un llit de Procust. Com que el text del ms. 9750 de la BNE, diguem-ne que «contradiu» la seua visió d'una llengua del Curial mancada de matisos diatòpics, doncs la van rectificant capriciosament. Amb aquest insòlit procediment d'edició crítica, és clar, acaben desdibuixant la coloració diatòpica, occidental i valenciana, del text. Tot això, sense advertir el lector, i en una edició que Badia i Torró volen presentar davant la crítica literària com «l'edició» canònica. 
Abel Soler. L'atribució hipotètica de Curial e Güelfa a Enyego d'Àvalos (Consideracions sobre un «informe» de L. Badia i J. Torró)

Caldrà tenir present la sinceritat de Lola Badia quan reconeixia davant un periodista: «Jo, com a editora de textos, tinc un problema, i és que sóc poc acurada. Necessito sempre que m’ho repassin» (L'Avenç, 389, Barcelona, 2010, p. 20). Doncs, sí.

\subsection{5. «Els copistes canviaven de llengua quan copiaven un manuscrit» (article de Badia $\mathrm{i}$ Torró per a El Temps, 04/04/2017)}

Segons Badia i Torró, els copistes modifiquen la llengua quan copien un manuscrit. ¿Fins al punt de «valecianitzar» una còpia del Curial destinada segurament a Toledo...? Si és així, hauríem de concloure que no són copistes d'un text literari, sinó impostors. L'afirmació qüestiona greument l'originalitat i la transmissió de la literatura. Ens hauríem de demanar, doncs, si la llengua d'una obra com Lo somni, de Bernat Metge, és de Bernat Metge o dels copistes que ens l'han transmesa. És obvi que la improvisada consideració de Badia i Torró sobre la llengua del Curial és un desesperat intent de «negan» les evidències lèxiques del Curial, perfectament documentades per Coromines, Colón, Veny i Ferrando.

Un copista difícilment pot evitar que la còpia ens reporte alguna petjada gràfica dels seus hàbits fonètics. I, si es tracta d'un text utilitari, destinat a un públic específic i diferenciat del receptor inicial, podria rastrejar-se aquesta presumpta manipulació morfològica o lèxica del text. Tanmateix, aquestes possibles alteracions sempre són l'excepció a la regla. Aquesta mena d'alteracions a penes es detecten en copistes competents, com és el cas de l'escrivà del Curial, reconegut com a molt eficient pels mateixos Badia i Torró (2011: 110). Per a ells, es tracta d'un «professional competent, atès el nombre reduïdíssim d'errades que ha calgut corregir-li». En el cas del Curial, no podem de cap manera atribuir les preferències lèxiques valencianes al copista del còdex, com volen ara fer-nos creure -a la desesperada- Badia i Torró. Suposant que fóra com ells volen, l'amanuense professional hauria d'haver reflectit en la còpia, espontàniament, uns altres trets lingüístics valencians, com ara la palatalització de la $s$ davant velar en vocables del tipus mereixca, o en els incoatius del tipus patix. O com els sufixos de bellea, etc. D'altra banda, els paleògrafs han assenyalat, per alguns indicis que sí que són atribuïbles a lapsus de l'escrivà, que aquest podria ser un aragonés.

\subsection{Badia: «El director de la tesi d'Abel Soler, Antoni Ferrando, que ara proposa D'Àvalos, fa poc que apostava per Joan Olzina, secretari del Magnànim, en un article d'Estudis Romànics 2013».}

El director de la nostra tesi ha contrastat sistemàticament i críticament, com és pertinent, tota la documentació relativa a la meua hipòtesi. L'any 1980 va proposar Olzina com a probable autor del Curial i va anunciar un estudi justificatiu de la hipòtesi. Després ja no hi ha insistit en cap treball posterior. Va presentar el Curial, en la seua edició filològica del 2007 (p. 27) com una obra anònima. L'estudi anunciat s'havia diferit per mancança d'indicis sòlids, però el va haver d'emprendre arran de la publicació de la hipòtesi de M. Teresa Ferrer (2011: 133) a favor de Lluís 
Abel Soler. L'atribució hipotètica de Curial e Güelfa a Enyego d'Àvalos (Consideracions sobre un «informe» de L. Badia i J. Torró)

Sescases. Ferrando publicà en Estudis Romànics (2013) un article titulat «Joan Olzina, secretari d'Alfons el Magnànim, autor del Curial»», que concloïa d'aquesta manera: «Així doncs, malgrat tots els indicis positius apuntats, no hi ha cap prova que permeta afirmar que Joan Olzina fos l'autor del Curial. Més aviat diria que els indicis dubtosos i negatius fan poc probable aquesta hipòtesi» (Ferrando 2013: 459). Antoni Ferrando diu exactament el contrari del que li atribueix Lola Badia.

\subsection{7. «A València els tenen tots, els escriptors, no els cal aquest també» (entrevista a Badia per a Vilaweb, 05/04/2017)}

Badia i Torró conclouen així el seu Informe (p. 17): «En el fons, que l'anònim autor de la novel la fos català o valencià, nat a Toledo o a qualsevol altre lloc, no hauria de preocupar gaire. Allò que resulta preocupant és que la filologia esdevingui un instrument al servei del particularisme». En la meua investigació, la vinculació valenciana d'Enyego d'Àvalos és una circumstància biogràfica que ajuda a entendre per què preferí recórrer a moltes paraules o variants expressives característiques del català de València. En realitat, preste molta major atenció a la italianitat contextual i cultural de l'obra, com la mateixa novel la demana, que als aspectes «particularistes» que tant interessen ara a Badia i Torró, però que són poc rellevants per a la història de la literatura catalana. De tota manera, aquesta no deixa de ser una dada especialment rellevant, i recolza la meua hipòtesi d'atribució del text a D’Àvalos. No m'identifique gens amb «tota aquesta passió per trobar-hi valencianismes» que m'atribueix obsessivament Badia (Vilaweb, 05/04/2017). A penes preste atenció als aspectes estrictament lingüístics. Simplement, remet als experts: als lingüistes.

Pel que s'observa, sembla preocupar molt a Badia i Torró -no arribem a copsar per quina raóque l'autor del Curial puga ser valencià o tenir vincles d'alguna mena amb València. D'ací que procuren ometre o negar qualsevol indici que permeta relacionar l'escriptor amb València o amb un entorn valencià: des de negar l'obvietat de les inclinacions lèxiques de la novel la, que delaten ostensiblement aquesta relació, fins a situar els vincles de l'autor amb Enric de Villena en unes indeterminades «corts ibèriques dels Trastàmara». Quan allò més lògic haguera sigut relacionar-les amb la cort valenciana d'Alfons d'Aragó-Trastàmara (1416-1430), on Villena solia residir llargues temporades $i$ on va nàixer probablement la seua filla natural, sor Isabel de Villena (ca. 1430-1490). En el fons, Badia i Torró massa sabien que l'autor del Curial es relacionava amb la cort reial de València, però l'inconscient els traeix i revela absurds prejudicis, d'aquells que interfereixen en la seua (in)comprensió de l'obra: «A València els tenen tots, els escriptors, no els cal aquest també» (Lola Badia, en a Vilaweb, 05/04/2017). En fi: un curiós espectacle de filologia provinciana. 
Abel Soler. L'atribució hipotètica de Curial e Güelfa a Enyego d'Àvalos (Consideracions sobre un «informe» de L. Badia i J. Torró)

\section{Reflexions finals i conclusions}

En llur Informe o autoinforme pamfletari, els professors Lola Badia i Jaume Torró (2017b: 17) s'han afanyat a cursar per les xarxes socials una delatora contradicció: «La tesi... s'haurà de jutjar quan es publiqui». I, tanmateix, no dubten de prejutjar el meu treball com una «hipòtesi sense fonament». Els fa patir que es publique. A partir d'allò que és només un avançament-forçosament simplificatdel meu treball ('article d'ER), i fent barreja amb dades descontextualitzades, volen desautoritzar una recerca que desconeixen.

No pretenc que tot allò exposat en més de 5.000 pàgines -una extensió que els sembla també impertinent- resulte impecable o incontestable. Quin treball de recerca és absolutament impecable? Ara bé, sí que puc garantir -en defensa meua- que és un treball metodològicament rigorós i honest, com cal. En el fons, Badia i Torró reconeixen implícitament que la hipòtesi és difícilment rebatible. Ells no han sabut trobar l'autor del Curial, però tampoc no celebraran mai que un altre ho puga fer o proposar metòdicament, ni tan sols en grau d'atribució hipotètica. S'expliquen així la reacció insolent a la qual hem hagut d'assistir, tristament, a través de la premsa periòdica. Sens dubte, la mancança de resultats que han obtingut en l'atribució d'autoria, al llarg dels darrers trenta anys de recerca, es deu a una desorientació apriorística: l'obsessió per una ubicació «ibèrica», però no valenciana (ni aragonesa) de l'obra... Constitueix un exemple de com el patriotisme mal entés, o els prejudicis particularistes, poden interferir en la investigació sobre literatura. D'altra banda, desconeixen moltes de les fonts italianes de l'obra, i són incapaços de situar el Curial en el context cultural i polític pertinent: la Itàlia del rei Alfons.

Si ara s'afanyen a rectificar precipitadament, fins i tot al preu de faltar a la veritat o de manejar arguments fal laciosos, és perquè saben que s'han equivocat, encara que no ho reconeguen. El relatiu silenci que fins ara havien mantingut sobre la hipòtesi de Ferrer i Mallol (que ja apuntava cap a Itàlia, correctament, i cap a l'entorn de Sescases, on es trobava D'Àvalos) contrasta vivament $-\mathrm{i}$ simptomàticament, val a dir- amb aquestes reaccions intempestives davant una hipòtesi derivada de pistes apuntades precisament per Ferrer: Sescases fou notari, arxiver i company de diplomàcia de D'Àvalos. Dedueixen que l'he encertada finalment, que no hi pot haver cap alternativa versemblant -i ens consta que no n'hi haurà- a l'atribució del Curial a Enyego d'Àvalos. Es comprén, en conseqüència, que els dolga, però resulta inadmissible que reaccionen amb una actitud acadèmicament tan poc respectuosa $i$, des d'una perspectiva moral, indecent $i$ poc mesurada.

Amb tot, Badia deixa entreveure la versemblança inqüestionable de la nostra hipòtesi en les seues declaracions periodístiques, poc elegants, però ben explícites pel que fa a la plasmació de contradiccions del tipus: «Saber la identitat de l'autor d'una obra és fonamental per a la crítica històrica. Ara bé, la crítica històrica també sap que, quan una cosa és inabastable, no és metodològicament admissible construir complexes compilacions de dades destinades a fer passar per certa una tria que té algunes possibilitats de ser certa, però cap prova determinant» (declaració per 
Abel Soler. L'atribució hipotètica de Curial e Güelfa a Enyego d’Àvalos (Consideracions sobre un «informe» de L. Badia i J. Torró)

a El Punt Avui, 16/03/2017). Evidentment, el mèrit del meu treball no consisteix a aportar cap prova determinant i apodíctica (potser mai no se'n trobe cap, com ja advertí Ferrer), sinó a identificar l'autor, situar l'obra en el seu context i interpretar-la com requereix, malgrat l'absència d'aquesta signatura explícita. Hi ha indicis suficients i signatures «implícites» que permeten atribuir l'obra a D'Àvalos. Si haguérem disposat d'una declaració formal d'autoria, doncs ens haguérem estalviat tot el treball de recerca. El mèrit resideix precisament en haver estretit el cercle entorn de l'autor, fins a identificar-lo, malgrat la pèrdua accidental, si és que existí, del material prologal de l'obra.

És comprensible. Els deu pesar no haver arribat ells a cap conclusió sobre l'autoria del Curial després de tants anys d'estudi. Com també els pesarà que la meua tesi pose en evidència les seues limitacions metodològiques a l'hora d'interpretar la novel la. De fet, no hi veuen més enllà de les dades purament literàries. I, encara quel els seus estudis en aquesta direcció filològica $\mathrm{O}$ historicoliterària són meritoris -i com a tals els considerem i citem reiteradament en els nostres-, manegen un deplorable boomerang quan es dediquen a desqualificar la meua tesi sense conéixer-la, a més d'atacar la Universitat de València, o àdhuc els avaluadors de l'acreditada revista Estudis Romànics. Ja no parlem de principis ètics, sinó d'una mancança clamorosa de respecte pels col legues de professió i de recerca, pels professionals i per les institucions. Comptat i debatut, Badia i Torró:

* Desautoritzen, menyspreen o silencien aquells punts de vista que no coincideixen amb els seus esquemes.

* Veuen en la meua hipòtesi una «apropiació provinciana» del Curial, quan allò que en realitat demostren ells és una obsessió regionalista o particularista, aliena a una visió global de la producció literària del segle XV en català.

* Desqualifiquen els controls de qualitat de la Universitat de València i de la revista Estudis Romànics, fins al punt de qüestionar l'autoritat de l'Institut d'Estudis Catalans, en nom d'una infal libilitat científica autoatribuïda en exclusivitat.

* S'autoerigeixen en dipositaris de la correcta, unívoca i inqüestionable interpretació del Curial, encara que siga, al nostre parer, tan errònia com desorientadora.

* Proclamen que han demostrat -ells!- que el context del Curial és la cort napolitana del Magnànim (2017), quan Badia parlava fins ahir mateix de l'escriptor com aquell «anonimo autore, di cui si ignora nome e contesto» (2016).

* Desautoritzen els màxims experts en lexicografia històrica catalana (Coromines, Colón, Veny) amb declaracions frívoles, sense aportar ni tan sols arguments.

* Han negat sempre la influència ideològica i literària de l'humanisme italià (Bruni, Barzizza, clàssics redescoberts, etc.) en el Curial, per tal que no perille l'artificiós vincle que han volgut sostenir 
Abel Soler. L'atribució hipotètica de Curial e Güelfa a Enyego d’Àvalos (Consideracions sobre un «informe» de L. Badia i J. Torró)

entre el text i un autor ancià, imitador de «cròniques catalanes» $\mathrm{i}$ vinculat a les «corts ibèriques dels Trastàmara».

* Amb aquest artifici, han desorientat acadèmicament els estudiosos de l'obra (ja ho van fer amb el Tirant, obra del cavaller de València Joanot Martorell, que confongueren amb un «ciutadà» homònim resident a Barcelona), però també han contribuït a desorientar editors d'enciclopèdies i redactors de llibres de text.

* I, per si fóra poc això, s’atribueixen mèrits que corresponen a altres professionals.

Davant d'aquesta situació, reivindique el meu dret $-\mathrm{i}$ el de qualsevol altre professional universitari- a estudiar i interpretar la novel la Curial e Güelfa amb els instruments que ens proporcionen la història medieval, la filologia, i altres disciplines humanístiques anàlogues o subsidiàries (heràldica, història de l'art, numismàtica, paleografia, etc.), que ens ajuden a interpretar i a comprendre el llegat literari en el context social, històric i cultural que pertoca. Reivindique, senzillament, el dret a la confrontació argumentada d'interpretacions sobre un tresor literari compartit per tota la comunitat lingüística catalana, sense necessitat de recórrer a anatemes cínics, desqualificacions infundades o reduccionismes regionalistes. La troballa de l'autoria de Curial e Güelfa no hauria de ser motiu de desavinences acadèmiques estèrils, sinó d'una celebració -críticament tamisada- per part dels estudiosos de la filologia catalana, de la història de la cultura i de la història medieval. 
Abel Soler. L'atribució hipotètica de Curial e Güelfa a Enyego d'Àvalos (Consideracions sobre un «informe» de L. Badia i J. Torró)

\section{Bibliografia}

Avenoza, G. (2012) «De nou sobre el ms. del Curial e Güelfa: una aproximació codicològica», dins Ferrando, A. (ed.), Estudis lingüistics $i$ culturals sobre «Curial e Güelfa», novel la cavalleresca anònima del segle XV en llengua catalana, Amsterdam, John Benjamins, vol. 1, pp. 3-20.

Badia, L. (1987 [1985]) «La segona visió mitològica de Curial i notes per a una interpretació de l'anònim català del segle XV», dins Beltran, V. (ed.) Actas del I Congreso de la Asociación Hispánica de Literatura Medieval (Santiago de Compostela, 2 al 6 de diciembre de 1985), Santiago de Compostela, pp. 157-176.

- (1988) «De la reverenda letradura en el Curial e Güelfa», dins De Bernat Metge a Joan Roís de Corella, Barcelona, Quaderns Crema, pp. 121-144.

- (2016) «Resenya a Curial e Güelfa, introduzione di Antoni Ferrando; traduzione di Cesáreo Calvo e Anna Giordano, Roma, Aracne, 2015», Llengua \& Literatura, 26, pp. 186-189.

Badia, L. \& Torró, J. (2010) «Curial entre Tristán y Orlando», dins Bautista, F. / Jimena Gamba, C. (eds.) Estudios sobre la Edad Media y la temprana Modernidad, San Millán de la Cogolla, Cilengua/ La Semyr, pp. 43-60.

—. (eds.) (2011) Curiale Güelfa. Edició crítica i anotada, Barcelona, Quaderns Crema.

- (2015) «Curial e Güelfa», dins Broch, A. (dir.) Història de la literatura catalana, vol. 3. Literatura medieval (III). Segle XV (dir. per L. Badia), Enciclopèdia Catalana/Barcino/Ajuntament de Barcelona, Barcelona, pp. 55-106.

. (2016) «Ressenya d'Anonimo, Curial e Güelfa, introduzione di Antoni Ferrando Francès, traduzione di Cesáreo Calvo Rigual e Anna Giordano Gramegna, Roma: Aracne, 2014», Llengua \& Literatura, 26, pp. 186-189.

. (2017a) «Sobre l'autoria de Curial e Güelfa: una noticia molt exagerada», El Temps, València/ Barcelona, 28/04/2017 [http://eltemps.cat/sobre-lautoria-de-curial-e-guelfa-una-noticia-moltexagerada/].

. (2017b) «Informe sobre la hipòtesi d'atribució de Curial e Güelfa a Íñigo d'Ávalos», ed. electrònica dins Narpan. Espai virtual de literatura $i$ cultura medieval <http://www.narpan.net/>, 20 pp.

- (2017c) «Informe sobre la hipòtesi d'atribució de Curial e Güelfa a Íñigo d’Ávalos», ed. electrònica dins Narpan. Espai virtual de literatura i cultura medieval $<$ http://www.rmoa.unina. it $/ 4551 />$.

Beltran, R. (2012) «El mariscal Boucicaut, Guillaume du Chastel i Pere de Cervelló al Curiale Güelfa i al Jehan de Saintré: connexions històriques i literàries», dins Ferrando, A. (ed.) Estudis lingüístics $i$ culturals sobre «Curial e Güelfa», Amsterdam, John Benjamins, vol. 1, pp. 157-200. 
Abel Soler. L'atribució hipotètica de Curial e Güelfa a Enyego d’Àvalos (Consideracions sobre un «informe» de L. Badia i J. Torró)

Briquet, C.-M. (1966), Les filigranes. Dictionnaire historique des marques du papier dès leur apparition vers 1282 jusqu'en 1600; avec 39 figures dans le texte et 16.112 fac-similes de filigranes, ed. per Allan Stevenson, 1907; reed. facsímil, Nova York, Hacker Art Books, 4 vol.

Butinyà, J. (1987-1988) «Sobre l'autoria del Curial e Güelfa», Boletín de la Real Academia de Buenas Letras de Barcelona, 41, pp. 63-119.

. (2001 [1a ed. 1999]) Tras los orígenes del humanismo: el «Curial e Güelfa», Madrid, Universidad Nacional de Educación a Distancia.

Butinyà, J. \& Gros, S. (2013) «Ressenya de Curial e Güelfa (2011): a cura de Lola Badia / Jaume Torró, Barcelona: Quaderns Crema, 755 p. (Sèrie Gran, 26)», Estudis romànics, 35, pp. 522-527.

Calvo, C. (2014) «Lingua toscana in bocca catalana: sull'italianità del Curial e Güelfa», dins Anonimo, Curial e Guelfa, trad. de Calvo, C. / Giordano Gramegna, A., Roma, Aracne, pp. 67-92.

Camps, E. (2017) «Entrevista a Lola Badia», Vilaweb, Barcelona, 08/05/2017, [http:/ /www.vilaweb. cat/noticies/lola-badia-els-que-hem-treballat-amb-el-curial-sabem-que-es-molt-dificil-fixar-nelautor-perque-no-hi-ha-cap-pista-material/].

Chilà, R. (2014) Une cour à l'epreuve de la conquête: la société curiale et Naples, capitale d'Alphonse le Magnanime (1416-1458), Tesi doctoral inèdita, Montpeller, Université Paul Valéry-Montpéllier III, 3 vol.

Colapietra, R. (2013) Napoli e il suo Regno. Studi di storia moderna e conteporanea, Nàpols, La scuola di Pitagora. Scuola di alta formazione dell’Istituto italiano per gli studi filosofici («Saggi e ricerche», 3).

Colón, G. (1985) «Era valencià l'autor del CuriaP», Boletín de la Sociedad Castellonense de Cultura, 61, pp. 83-91; reed. dins Colón, G., Problemes de la llengua a València i als seus voltants, València, Universitat de València, 1987, pp. 43-53.

. (2011) «Curial e Güelfa: català o valencià?, Lexicografia, lèxic i crítica textual», Barcelona, Publicacions de l'Abadia de Montserrat, pp. 283-290.

De Rosa, L. (1998) Ricordi. Ed. critica del ms. ital. 913 de la Bibliothèque nationale de France, ed. a cura de V. Formentin, Roma, Salerno, 2 vol.

Deyermond, A. D. (2002) «La micropoética de las invenciones», dins Casas, J. / Díaz, E. (eds.) Iberia cantat. Estudios sobre poesía hispánica medieval, Sant Jaume de Galícia, Universidad de Santiago de Compostela, pp. 403-424.

Espadaler, A. M. (1984) Una reina per a Curial, Barcelona, Quaderns Crema.

Ferrando, A. (1980) Consciència idiomàtica i nacional dels valencians, València, Universitat de València.

. (1996), «Sobre el marc històric de Curial e Güelfa i la possible intencionalitat de la novel la», dins Barberà, J. M. (ed.), Actes del Col loqui Internacional «Tirant lo Blanch: l'albor de la novel la moderna» (Ais de Provença, 21-22 d'octubre de 1994), Barcelona, Centre Aixois de Recherches Hispaniques/ Institut Interuniversitari de Filologia Valenciana/Publicacions de l'Abadia de Montserrat, 1997, pp. 323-369. 
Abel Soler. L'atribució hipotètica de Curial e Güelfa a Enyego d'Àvalos (Consideracions sobre un «informe» de L. Badia i J. Torró)

(ed.) (2012a [2007-2010]) Estudis lingüistics $i$ culturals sobre «Curial e Güelfa», novel la cavalleresca anònima del segle XV en llengua catalana, Amsterdam, John Benjamins.

(2012b) «Precaucions metodològiques per a l'estudi lingüístic del Curial e Güelfa», dins Ferrando, A. (ed.) Estudis lingüistics $i$ culturals sobre «Curial e Gü̈lfa», novel tla cavalleresca anònima del segle XV en llengua catalana, Amsterdam, John Benjamins, pp. 31-88.

__. (2013) «Joan Olzina, secretari del Magnànim, autor del Curial e Güelfa?», Estudis Romànics, 35, pp. 443-463.

Ferrer Mallol, M.-T. (2011) «Fou Lluís Sescases l’autor de Curial e Güelfa? El Nord d'Àfrica en la narrativa del segle XV», dins Bellveser, R. (coord.), La novel la de Joanot Martorell i l'Europa del segle XV, València, Institució Alfons el Magnànim, vol. 1, pp. 59-142.

Lladó, A. (2017) «Los misterios de Curial e Güelfa», Suplemento cultural de La Vanguardia, Barcelona, 25/03/2017 [http://www.lavanguardia.com/cultura/20170325/421156215045/misterios-curiale-guelfa.html].

Llort, L. (2017) «Pugnes científiques», El Punt-Avui, Barcelona, 16/03/2017 [http://www. elpuntavui.cat/cultura/article/19-cultura/1094116-pugnes-cientifiques.html].

Mena, J. de (1996) La «Iliada» de Homero (ed. crítica de las «Summas de la Ylíada de Omero» y del original latino reconstruído, acompañada de un glosario latino-romance), ed. a cura deT. González, Ma . F. del Barrio i A. López, Madrid, Ediciones Clásicas.

Miquel Planas, R. (ed.) (1932) Curial e Güelfa, Barcelona, Biblioteca Catalana.

Miranda Menacho, V.-C. (2011) Elpríncipe de Viana en la Corona de Aragón (1457-1461), Tesi doctoral inèdita, Barcelona, Universitat de Barcelona.

Monneret de Villard, U. (1954-1956) «Le filigrane delle carte milanesi delle più antiche alla fine del XV secolo», Archivio storico lombardo(s. 8), vol. 5, fascs. 81-82, pp. 24-55.

Pedralli, M. (2002) «Novo, grande, coverto e ferrato». Gli inventari di biblioteca e la cultura a Milano nel Quattrocento, Milà, Vita e pensiero.

Rubió Balaguer, J. (1953) «Historia de la literatura catalana», dins Díaz-Plaja, G. (dir.)Histoira general de las literaturas hispánicas, vol. 1 i 2, Barcelona, Vergara; reed. com Història de la Literatura Catalana (Obres Completes de Jordi Rubió i Balaguer, I), Barcelona, Generalitat de Catalunya/Publicacions de l'Abadia de Montserrat, 1984.

Rubio Vela, A. (2011) «Se escribió el Tirant lo Blanch en la corte barcelonesa del príncipe de Viana? Notas de crítica documental entorno a un espejismo literario», eHumanista,19, pp. 345-356.

Sánchez, A. (2012) «Nuevas observaciones sobre la encuadernación del Ms. 9750, Curial e Güelfa, de la Biblioteca Nacional de España», dins Ferrando, A. (ed.) Estudis lingüístics i culturals sobre «Curial e Güelfa», novel ta cavalleresca anònima del segle XV en llengua catalana, Amsterdam, John Benjamins, vol. 1, pp. 105-110. 
Abel Soler. L'atribució hipotètica de Curial e Güelfa a Enyego d’Àvalos (Consideracions sobre un «informe» de L. Badia i J. Torró)

Serra, L. (2017) «Dir el nom de l'autor del Curial e Güelfa es "gratuit i acientífic"», Ara.cat, Barcelona, $11 / 03 / 2017$.

Soler, A. (2014) «Joanot Martorell, "cavaller habitador de la ciutat de València”. Nous documents sobre els darrers anys de l'autor de Tirant lo Blano», eHumanista/IVTTRA, 5, pp. 467-502.

- (2016) «Iconografia italiana i literatura cavalleresca catalana: les al legories de les arts liberals en Curial e Güelfar, dins V. Orazi i al. (eds.) Linguaggi del metareale nella cultura catalana, Torí, Dipartimento di Lingue e letterature straniere e culture moderne/Università di Torino («QuadRi-Quaderni di RiCOGNIZIONI», 3), pp. 41-57.

—. (2017) «Enyego d'Àvalos, autor de Curiale Güelfa?», Estudis Romànics, 39, Barcelona, pp. 137-165.

—. (en premsa) «L'entorn valencià d'Enyego d'Àvalos i l'autoria de Curial e Güelfa», eHumanistal IVITRA, 11.

Stocchi, M. (1995-1996) «Curial e Güelfa e il Decamerone», Boletin de la Real Academia de Buenas Letras de Barcelona, 45, pp. 295-316.

Torró, J. (2001) «Una cort a Barcelona per a la literatura del segle XV», Revista de Catalunya, 163, Barcelona, pp. 97-123.

—_. (2002) «Joanot Martorell, escrivà de ració», L'Avenç, 273, pp. 12-18.

(2012) «Només hi ha un Joan Martorell documentat amb el nom de Joanot (Resposta i correcció a Agustín Rubio Vela, amb unes notes sobre Manuel de Rajadell)», Tirant, 15, pp. 19-32.

Veny, J. (2012) «Valencianitat del Curiah, dins Ferrando, A. (ed.) Estudis lingüistics $i$ culturals sobre "Curial e Güelfa», novel la cavalleresca anònima del segle XV en llengua catalana, Amsterdam, John Benjamins, vol. 2, pp. 1089-1126.

- (2017) «Curial u Güelfai el valencià», Barcelona, Institut d'Estudis Catalans, edició electrònica [www.iec.cat/Comunicació_IEC/Veny_Curial_i_el_valecià.pdf].

Zurita, J. (1970-1998 [1562]) Anales de la Corona de Aragón, ed. a cura d'A. Canellas López, Saragossa, CSIC/Institución Fernando el Católico. 